The Cryosphere Discuss., https://doi.org/10.5194/tc-2017-97

Manuscript under review for journal The Cryosphere

Discussion started: 15 June 2017

(c) Author(s) 2017. CC BY 3.0 License.

\title{
Water flow in the active layer along an arctic slope - An investigation based on a field campaign and model simulations
}

\author{
Sebastian F. Zastruzny ${ }^{1}$, Bo Elberling ${ }^{2}$, Lars Nielsen ${ }^{1}$ Karsten H. Jensen ${ }^{1}$ \\ ${ }^{1}$ Department of Geoscience and Natural Resource Management, University of Copenhagen, Copenhagen, 1350, Denmark \\ $5{ }^{2}$ Center for Permafrost (CENPERM), Department of Geosciences and Natural Resource Management, University of \\ Copenhagen, Copenhagen, 1350, Denmark
}

Correspondence to: K. H. Jensen (khj@ign.ku.dk)

\begin{abstract}
As climate conditions change, the hydrological regime in the active layer is subject to change too. This influences the transport of solutes and the availability of nutrients, e.g. nitrogen particularly, along slopes. There is a lack of understanding the pathways and travel times of water and nutrients along slopes in discontinuous permafrost regions and how to scale changes along transects to the rest of the landscape. This study presents a comprehensive data set of a field site in Disko Island in Greenland aiming at constructing a hydrological model of the area. Data from automated weather stations, geophysical surveys, soil samples and soil sensors and tracer experiments are combined to describe the spatial variability in the field and to serve as input to a two-dimensional model (SUTRA) for simulating water and solute transport in the summer

15 period. The model is calibrated and validated against volumetric water content and breakthrough curves of the applied tracers. Observed and simulated results suggest that the flow velocity in the active layer is directly influenced by annual precipitation patterns leading to water flow during the summer and rapid movement at the end of summer. Yearly travel times for the specific field site are simulated to be approximately $14 \mathrm{~m} / \mathrm{a}$ and the highest peak velocities are most likely caused by preferential flow paths. The spatial heterogeneities linked to the frost topography seem to control the direction and velocity of flow. The observed discontinuous movement of a conservative tracer suggests that the movement of dissolved nitrogen compounds such as nitrate, being released along the slope in consequence of permafrost thawing, could possibly quickly influence nitrogen cycling at the end of the slope. This may trigger a feedback of climate changes in terms of increasing carbon sequestration due to additional plant growth in these otherwise nitrogen-limited Arctic ecosystems.
\end{abstract}


The Cryosphere Discuss., https://doi.org/10.5194/tc-2017-97

Manuscript under review for journal The Cryosphere

Discussion started: 15 June 2017

(c) Author(s) 2017. CC BY 3.0 License.

\section{Introduction}

The active layer is the uppermost zone of the ground characterized by annual thaw-freeze cycles. The layer is in direct contact with the atmosphere and provides the basis of vegetation growth and is therefore an important part of permafrostaffected arctic ecosystems (Bonnaventure and Lamoureux, 2013). As a result of infiltration, a thin saturated layer is commonly formed at the base of the active layer and on top of the mostly impermeable permafrost table. Exchange with deeper groundwater is only possible if open taliks connect the active layer to deeper aquifers (Bense et al., 2012). The typical seasonal recharge pattern in arctic regions is characterised by two large events: Snowmelt at the beginning of summer and increased precipitation at the end of summer. In the main growing season in between, water storage and flow decline as evaporation exceeds precipitation except during short-duration precipitation events (Ireson et al., 2012).

10 Permafrost inhibits mixing of supra-permafrost and sub-permafrost water (Tetzlaff et al., 2015), leading to longer travel times in the sub-permafrost aquifer and shorter solute travel times in the supra-permafrost aquifer (Frampton et al., 2011). The velocity and direction of flow in the active layer is controlled by the topography of the frost table, which acts as an impermeable barrier and therefore controls the flow pathways (Wright et al., 2009). The microtopograhpy of the frost table creates a complicated flow networks that also lead to lateral flow (Atchley et al., 2015). Models capable of simulating the complex mechanisms occurring in cold climate environment have only recently emerged (Kurylyk et al., 2014) and are still under development.

An increase in average annual air temperature (IPCC, 2014) may lead to a thicker active layer by the end of the growing season as well as the formation of taliks and increased erosion which have implications for both the natural ecosystem and infrastructure (Jorgenson et al., 2010). Part of these impacts are directly linked to changes in the hydrological conditions (Bense et al., 2009) with profound changes in the permafrost hydrology, active soil moisture distribution and flow patterns (Bring et al., 2016). The deepening of the active layer will change the flow and transport pattern and typically lead to longer travel paths and times (Frey and McClelland, 2009;Frampton and Destouni, 2015). An ecological effect is related to the release and subsequent migration of inorganic nitrogen stored in the perennially frozen ground (Elberling et al., 2010) or from winter decomposition (Blok et al., 2016). These two processes occur at different times during the year and release nitrogen at different depths in the active layer. The production and transport of nitrogen in the active layer depends heavily on the depth where flow is occurring. With increased depth the effect of denitrification is reduced which increases the net export of nitrogen (Harms and Jones, 2012).

This phenomenon will particularly occur at sloping locations with high hydraulic gradient where the released nitrogen can be transported by water and supply nutrients to the low-lying wetlands in the arctic. Yano et al. (2010) applied ${ }^{15} \mathrm{~N}$ to the surface and their results confirmed that production and transport of nitrogen in the active layer depend on depth, with water playing the single most important role in the mobilization. They developed a conceptual model that emphasizes the differences between flow in the uppermost layer and flow in deeper layers where export of nitrogen is possible due to lack of 
The Cryosphere Discuss., https://doi.org/10.5194/tc-2017-97

Manuscript under review for journal The Cryosphere

Discussion started: 15 June 2017

(c) Author(s) 2017. CC BY 3.0 License.

nitrogen sinks. Harms and Jones (2012) adopted this conceptual model, but applied ${ }^{15} \mathrm{~N}$ at the base of the thaw layer by using a push-pull method. They also observed that nitrogen uptake occurred mostly during snowmelt in shallow soils with uptake rates significantly lower in summer and autumn, allowing for export of nitrogen from soils to lower lying wetlands or streams. Similar findings were achieved by using a water mass balance model and nitrogen flux model showing that during snowmelt a catchment can be a sink for water but at the same time be a source of nitrogen because of mobilization (Petrone et al., 2007). In a different study Harms and Ludwig (2016) showed that nitrogen concentrations are significantly related to water residence times, which differ in so called water tracks, channels found on arctic slopes draining an enhanced soil moisture zone (McNamara et al., 2008) and non-water tracks. They concluded that water tracks may augment the inorganic nitrogen reaching downslope ecosystems. Observations from long-term summer warming experiments in NW Greenland

10 showed that warmer conditions accelerate biological processes of nitrogen transformation and wetter conditions lead to increased soil hydraulic conductivity, changed pathways of nitrogen transformation and extended periods of microbial activity (Schaeffer et al., 2013).

Several studies have emphasized the need for combined field experiments and modelling in order to address the knowledge gaps in permafrost hydrology related to water flow and transport in permafrost-affected sediments (e.g. Ireson et al.,

15 2012;Bring et al., 2016). The objective of the present study is to quantify water flow and transport mechanisms in the active layer along an arctic hill slope with particular focus on the potential transport mode and time for nutrients released upstream. The study is based on comprehensive hydrogeological and geophysical field experiments and observations in combination with numerical modelling of flow and transport in the active layer. Tracer experiments were carried out to obtain field evidence on the transport behaviour of an inert solute and hereby the migration of nutrients released in thawing permafrost on arctic slopes. The study is based on an underlying hypothesis that nutrients released from different parts of the landscape may be transported to the bottom of hill slopes and here trigger an ecosystem response due to the additional water and nutrients.

\section{Description of Study Area}

The study area is located on Disko Island in Greenland $\left(69^{\circ} 27^{\circ} \mathrm{N}, 53^{\circ} 46^{\circ} \mathrm{W}\right.$ ) (Fig. 1a) on the border between high and low

25 arctic conditions. The climate is classified as maritime low arctic with an annual average air temperature of $-3.3^{\circ} \mathrm{C}$ for the period 1991-2004 and with maximum in July (mean monthly average $7.1^{\circ} \mathrm{C}$ ) and minimum in February-March (mean monthly average $-16^{\circ} \mathrm{C}$ ) (Hansen et al., 2006b). For the observation period 1991-2011, the mean annual air temperature has increased by $0.2^{\circ} \mathrm{C}$ per year (Hollesen et al., 2015) now reaching near zero as the annual mean air temperature. Positive daily average air temperatures are typically between May and September (Hansen et al., 2006b). Precipitation as rain is $273 \mathrm{~mm}$ 
The Cryosphere Discuss., https://doi.org/10.5194/tc-2017-97

Manuscript under review for journal The Cryosphere

Discussion started: 15 June 2017

(c) Author(s) 2017. CC BY 3.0 License.

with September being the wettest month; while precipitation as snow corresponds to $200 \mathrm{~mm}$ water equivalents (Hansen et al., 2006b).

The permafrost distribution on Disko Island is characterized as being continuous (Humlum, 1998) while recent temperature changes suggest more discontinuous permafrost (Hollesen et al., 2015). This is in line with the general trend of the climate model predictions of the future climate of Greenland where permafrost temperatures are expected to increase which result in an associated increase in the thickness of the active layer (Daanen et al., 2011). The conditions of Disko Island are prone to change from a previous continuous permafrost area to a discontinuous area in consequence of changing climate.

The landscape is shaped by the Weichselian ice until 10.000 years ago and consists of glacial valleys eroded into basaltic layers and deposited tills. The retrieving glaciers left behind moraines of unsorted material, containing material of basaltic origin with a high percentage of iron (Pedersen et al., 2006). The field site is situated on a south-facing slope stretching $80 \mathrm{~m}$ in length between $110 \mathrm{~m}$ and $125 \mathrm{~m}$ a.s.1., on a moraine ("Pjeturssons Moræne") (Fig. 1b). The moraine stretches perpendicular in a valley ("Blaesedalen") and has a total extent of $1 \mathrm{~km}$ westwards from the site, where it is cut off by a river ("Rød Elve"). At the foot of the moraine is a wetland and $50 \mathrm{~m}$ further west of the profile under investigation, a lake. The wetland is separated by a small depression, which becomes a small creek after heavy rainfalls. The moraine continues north

15 of the field site to a total altitude of $153 \mathrm{~m}$ a.s.l. A regional DEM of Disko Island is available from the WorldView-2 satellite.

The study area is selected as being as representative as possible for slopes in West Greenland and it exhibits typical features such as a diplotelmic activ layer, variable vegetation pattern and irregular occurrence of water flow. As located at the border between high and low arctic, the site is expected to be in the front line of climate change and the change from continous to

20 discontnous permafrost (Hansen et al., 2006a). The field site was established in August 2015 and the field investigations and data collection were carried out during the period August 4-27, 2015.

\section{Materials and methods}

\subsection{Climate variables}

An automated weather station (AWS3) is located $300 \mathrm{~m}$ from the field site. Since 2012 data are supplied at 30 minutes

25 intervals for precipitation (Campbell Scientific, ARG1000), air temperature (Campbell Scientific, CS215), wind speed and direction (Campbell Scientific, A100R) and soil water content at 5, 10, 20 and $30 \mathrm{~cm}$ depths (Campbell Scientific, SM300). An additional weather station (AWS2) located $3 \mathrm{~km}$ south-west from the site is measuring net radiation (Kipp \& Zonen CNR4) and ground heat flux at $5 \mathrm{~cm}$ depth (Campbell Scientific HFP01SC-10) at 30 minutes intervals as well as snow depth (Campbell Scientific, SR50A).

30 To calculate evapotranspiration (ET) the Priestly-Taylor method (Priestley and Taylor, 1972) was used: 
The Cryosphere Discuss., https://doi.org/10.5194/tc-2017-97

Manuscript under review for journal The Cryosphere

Discussion started: 15 June 2017

(c) Author(s) 2017. CC BY 3.0 License.

$\mathbf{E T}=\frac{\mathbf{Q}_{\mathrm{E}}}{\rho_{\mathrm{W}} \cdot \mathbf{L}_{\mathbf{v}}}=\frac{1}{\rho_{\mathrm{w}} \cdot \mathbf{L}_{\mathbf{v}}} \boldsymbol{\alpha}_{\mathrm{PT}} \cdot \mathbf{f}(\boldsymbol{\theta}) \cdot\left(\frac{\mathbf{s}}{s+\gamma}\right) \cdot\left(\mathbf{Q}_{\mathbf{N}}-\mathbf{Q}_{\mathrm{G}}\right)$

where $Q_{E}$ is the energy used for evapotranspiration, $Q_{G}$ is the ground heat flux and $Q_{N}$ is the net radiation both measured at

5 AWS2, s is the slope of the saturation vapour pressure curve dependent on temperature, $\gamma$ is the psychometric constant, $L_{V}$ is the latent heat of vaporization, and $\rho_{w}$ is the density of water. The coefficient $\alpha_{P T}$, accounting for the ratio between potential evapotranspiration and equilibrium potential evaporation (Woo, 2012), is set to 1.26 as commonly assumed (Priestley and Taylor, 1972). The penalty function $f(\theta)$ accounts for the reduction in ET for water limiting conditions. Here we assume a simple penalty function which varies linearly with the water content $(\theta)$, between the values for field capacity $\left(\theta_{F C}\right)$, and permanent wilting point $\left(\theta_{P W P}\right)$, respectively:

$\mathbf{f}(\boldsymbol{\theta})=\frac{\boldsymbol{\theta}-\boldsymbol{\theta}_{P W P}}{\boldsymbol{\theta}_{F C^{-}-\boldsymbol{\theta}_{P W P}}}$

The snow water equivalent (SWE) is calculated based on the formula by DeWalle and Rango (2008):

15

SWE $=d_{\text {snow }} \frac{\rho_{\text {snow }}}{\rho_{\text {water }}}$

where $d_{\text {snow }}$ is the depth of snow, $\rho_{\text {water }}$ is the density of water, and $\rho_{\text {snow }}$ is the density of snow.

\subsection{Soil parameters}

20 Undisturbed and depth-specific volumetric soil samples $(n=24)$ were collected from 11 locations along a transect along the hill slope and down to $50 \mathrm{~cm}$ depth (Fig. 2). The samples were kept in airtight containers for analysis in the laboratory. Soil properties were measured in the laboratory according to standard methods (Blume et al., 2011): carbon content $(C)$ was measured by incarnation at $1350^{\circ} \mathrm{C}$, porosity $(n)$ and dry bulk density $\left(\rho_{d r y}\right)$ were determined by gravimetric methods, and saturated hydraulic conductivity $\left(K_{S}\right)$ was measured using a flow cell. At the sample locations, the bulk heat capacity $\left(c_{w}\right)$ and bulk thermal conductivity $\left(K_{T}\right)$ of the soil were measured in situ with a KD2 (Decagon Devices) at 10 cm intervals. 
The Cryosphere Discuss., https://doi.org/10.5194/tc-2017-97

Manuscript under review for journal The Cryosphere

Discussion started: 15 June 2017

(c) Author(s) 2017. CC BY 3.0 License.

\subsection{Soil moisture, temperature and electric conductivity}

A total of 14 sensors (Decagon Devices 5TE) were installed at the site for measurements of volumetric water content $(\theta)$, soil temperature $\left(T_{\text {soil }}\right)$, and bulk electric conductivity $\left(\sigma_{b}\right)$. The sensors were installed at the top, middle and bottom of the transect at depths between 10 to $50 \mathrm{~cm}$ below ground (Fig. 2). The sensors were connected to a data logger 5 (Campbell EM50) that monitored at 30 min intervals.

\subsection{Geophysical Imaging}

Four multi-electrode electrical profiling (MEP) arrays were made to assess the presence and extent of frozen ground (Fig. 2). For data acquisition a Supersting R8 from AGI Geo was used. Electrodes were attached to pin electrodes that were placed in the ground to a depth of approximately $30 \mathrm{~cm}$. Contact of the electrodes was ensured by a self-testing mechanism of the

10 acquisition system. A data acquisition strategy based on a Wenner configuration was chosen because only limited horizontal variability of subsurface structures was expected and the primary focus was on delineation of horizontal layering of the subsurface (Ishikava, 2008). For the N-S profile 54 electrodes were installed along the line with a spacing of $1.5 \mathrm{~m}$, yielding a profile length of $81 \mathrm{~m}$, with $0 \mathrm{~m}$ profile distance located close to the foot of the slope. In order to allow for deeper penetration depth at the corners and to capture heterogeneity perpendicular to the N-S profile, three additional profiles $\mathrm{W}$-E

15 profiles were collected using 56 electrodes with a spacing of $2 \mathrm{~m}$, yielding profile lengths of $110 \mathrm{~m}$, relative to the $\mathrm{N}-\mathrm{S}$ at the positions $7.5 \mathrm{~m}$ ('Bottom'), $31.5 \mathrm{~m}$ ('Middle') and $68.5 \mathrm{~m}$ ('Top'). The thickness of the active layer was measured using a stick probing at least every $2 \mathrm{~m}$ along the transect and used to validate/constrain the results based on the MEP independently.

The MEP data was processed and inverted using the software RES2DINV, which relies on an iterative smoothnessconstrained least squares inversion method (Loke, 2015). In order to obtain optimal results, noise, i.e. data points that showed quite strong and physically unrealistic deviation from neighbouring data points, were excluded manually from the modelling processes (Ishikava, 2008). For all profiles, convergence was reached after a maximum of five iterations. The convergence criteria used was that the relative change in root-mean-square value of the fit between observed and modelled data points changed by less than $5 \%$ or exceeded 5 iterations. The topography along the MEP profiles was extracted from a 25 local digital elevation model (D'Imperio et al., 2017) and included in the modelling.

Supplementary to the ERT data, Ground Penetrating Radar (GPR) profiles were collected in order to provide independent geophysical constraints on the depth to the permafrost layer (Jørgensen and Andreasen, 2007;Gacitúa et al., 2012). 
The Cryosphere Discuss., https://doi.org/10.5194/tc-2017-97

Manuscript under review for journal The Cryosphere

Discussion started: 15 June 2017

(c) Author(s) 2017. CC BY 3.0 License.

\subsection{Tracer Experiment}

Salt $(\mathrm{NaCl})$ was used as an inert solute tracer for mapping the flow pattern and transport times at the site. A total of $3.3 \mathrm{~kg}$ of salt was diluted in 101 of water to obtain a $\mathrm{NaCl}$ solution that could be traced by measuring bulk electric conductivity $\sigma_{b}$ of the soil. The tracer was added into a $30 \mathrm{~cm}$ wide trench dug to the permafrost base on August 6, 2015 at 16:00 at two positions, $35.8 \mathrm{~m}$ and $65.4 \mathrm{~m}$ from the foot of the slope. The tracer concentration was designed such that the plume migration could be monitored by the Decagon sensors, one at the top position and five at the middle position.

To capture the two-dimensional spreading of the tracer, the electric conductivity (EC) of the soil was additionally measured on a grid array with $50 \mathrm{~cm}$ spacing four times at dates August 13,16, 21 and 27. The measurements were carried out using an auger (diameter $1 \mathrm{~cm}$ ), which was inserted into the soil at the grid points until solid ground was hit. The lower $15 \mathrm{~cm}$ of

10 the core were diluted in $100 \mathrm{ml}$ distilled water and the resulting EC of the suspension was measured with an EC-Meter (Hanna Instruments, HI99300) and back calculated to represent the EC of the solution phase. At the $50 \mathrm{~cm}$ grid the surfaceand permafrost topography was recorded by measuring the distance to a horizontal arbitrary plane above the surface and interpolating between data points.

\subsection{Numerical flow and transport modelling}

15 The model code SUTRA 2.2 (Voss and Provost, 2010) was used for analysing the data from the field site. The code is capable of simulating unsaturated fluid flow as well as heat and solute transport. Refreezing and thawing during the summer period is not considered. Furthermore, it is assumed that the active layer depth does not vary over the considered season and flow and transport are only simulated in a two-dimensional cross-section along the hill slope.

20 Given these assumptions the governing equation for fluid flow reads:

$\frac{\partial\left(n S_{w}\right)}{\partial t}=\nabla[K(\theta) \cdot \nabla \mathbf{h}]-\mathbf{q}$

where $\mathrm{n}$ is the porosity, $\mathrm{S}_{\mathrm{w}}$ is the water saturation, $\mathrm{t}$ is the time, $\mathrm{K}(\theta)$ is the unsaturated hydraulic conductivity, $\mathrm{h}$ is the hydraulic head and $\mathrm{q}$ is a sink term representing evapotranspiration.

25 For the retention and hydraulic conductivity functions we assume that the van Genuchten-Mualem relationships are applicable (Van Genuchten, 1980). For retention this relationship is defined as:

$S_{e}=\frac{S_{w}-S r}{1-S r}=\left(1+\left(a_{V N} p_{c}\right)^{n_{V N}}\right)^{-1+\frac{1}{n_{V N}}}$ 
The Cryosphere Discuss., https://doi.org/10.5194/tc-2017-97

Manuscript under review for journal The Cryosphere

Discussion started: 15 June 2017

(c) Author(s) 2017. CC BY 3.0 License.

where $S_{e}$ is the effective saturation, $S_{w}$ the saturation, $S_{r}$ is the residual saturation, $\alpha_{V N}$ and $n_{V N}$ are soil specific empirical values respectively, and $p_{c}$ the capillary pore pressure. The relationship for unsaturated hydraulic conductivity $K(\theta)$ is defined as:

$5 \quad K(\theta)=K_{S} S_{e}^{0,5}\left[1-\left(1-S_{e}^{\frac{n_{V N}}{n_{V N}-1}}\right)^{\frac{n_{V N}-1}{n_{V N}}}\right]^{2}$

where $K_{s}$ is the saturated hydraulic conductivity.

For solute transport simulations it is assumed that the tracer is inert, thus the solute transport is calculated based on the advection-dispersion equation:

$\frac{\partial\left(n \rho S_{e} c\right)}{\partial t}=\nabla\left[n \rho S_{w} \mathrm{D} \cdot \nabla \mathrm{c}\right]-\nabla\left(v n \rho S_{w} c\right)$

where $\mathrm{c}$ is the concentration, $\mathrm{D}$ is the dispersion coefficient and $\mathrm{v}$ is the fluid velocity. The change in density based on the concentration of solute in the tracer liquid is calculated after McCutcheon et al. (1993).

\section{Results}

\subsection{Soil parameters}

All soil parameters were depth related reflecting an organic layer covering a lower mineral layer. Porosity and carbon content exhibited a clear difference between an upper organic and mineral soil layers (Fig. 3a). Average values for the porosity were $94.7( \pm 2.6) \%$ and $67.6( \pm 11.4) \%$ for the organic and the mineral layer, respectively, and for the carbon content $37.8( \pm 3.7) \%$ and $7.9( \pm 5.1) \%$, where numbers in brackets represent the standard deviations. Figure 4 shows that the interpolated boundary varied between 12 and $28 \mathrm{~cm}$ below surface, with the active layer consisting entirely of organic material at some localities along the profile. Dry bulk density had values of $113.5( \pm 58.5) \mathrm{g} / \mathrm{l}$ and $831.5( \pm 308.7) \mathrm{g} / \mathrm{l}$ for the organic and the mineral layer, respectively. The high standard deviation for the mineral layer is a result of the high

25 variability in clay, silt and sand fractions, which also is manifested in a high variability in hydraulic conductivity values. The hydraulic conductivity values of the organic layer were fairly high $654.7( \pm 133.5) \mathrm{cm} / \mathrm{d}$ due to fibrous appearance of the 
The Cryosphere Discuss., https://doi.org/10.5194/tc-2017-97

Manuscript under review for journal The Cryosphere

Discussion started: 15 June 2017

(c) Author(s) 2017. CC BY 3.0 License.

organic material and high porosity. The average hydraulic conductivity of the mineral layer was only slightly lower 279.2 $( \pm 279.7) \mathrm{cm} / \mathrm{d}$, but on the other hand the variability for this layer was much higher (Fig. 3b).

The vegetation varied according to the distribution of soil characteristics, mainly related to differences in soil moisture, grain size distribution and active layer depth. For the upstream part of the slope, soils below the organic layer consisted primarily of medium to coarse grained sand with an active layer depth $>100 \mathrm{~cm}$, while at the downhill locations soils were made up of silt or fine sand composition. Active layer probing at this location revealed thickness up to a depth of $>120 \mathrm{~cm}$.

\subsection{Moisture content variations}

The volumetric water content $\theta$ (Fig. 5) varied between 0.3 and 0.8 for all sensors except at location $\mathrm{Mid}_{3}$, where values of about 0.2 were measured until the August 28. Water contents were rather stable but increased abrupt due to rainfall events.

10 Stable values after September 29 are due to freezing conditions which is confirmed by soil temperature measurements. Very stable values are observed for sensor locations Bot $_{\mathrm{W}, \mathrm{D}}$ and $\mathrm{B}_{\mathrm{W}, \mathrm{S}}$ from August 29 suggesting that saturation of the soil was obtained implying porosity values 0.4 and 0.6 , respectively. The water saturated conditions at Bot $\mathrm{W}, \mathrm{D}_{\mathrm{D}}$ are confirmed for the period from the August 8 until August 27 by direct observation in a dug trench, close to the location.

\subsection{Inversion results and conceptual model of the site}

15 A conceptual model of the field site was developed based on the topography and measurements of the active layer depth with a probe. The lower boundary of frozen material was estimated by electric resistivity tomography (ERT) that penetrated to a maximum depth of $20 \mathrm{~m}$ below the surface. The boundary between frozen and unfrozen sediment was found to correspond to a resistivity of approximately $1000 \Omega \mathrm{m}$, based on comparison with the frost probing depth in the active layer (Fig. 6). Reflectivity observed in GPR data collected along the same line supports the interpretation of permafrost made based on

20 frost probing depth (Fig. 4) and ERT data. Based on fitting of hyperbolas observed in the reflection image, an average velocity of $0.057 \mathrm{~m} / \mathrm{ns}$ was estimated, which was subsequently used for migration and depth conversion (Neal, 2004). A reflection interpreted to represent the top of the permafrost layer is found at approximately $0.4 \mathrm{~m}$ depth at the downhill part of the transect (Fig. A2). This reflection is found a greater depth (about 0.5-0.6 m depth) from approximately $6 \mathrm{~m}$ profile distance until approximately $14 \mathrm{~m}$ profile distance from where is gradually becomes shallower until it reaches a depth of only about $0.3 \mathrm{~m}$ depth from approximately $18 \mathrm{~m}$ profile distance and onwards. It should be noted that from 7 to $14 \mathrm{~m}$ profile distance, relatively strong GPR reflectivity is observed 0.1-0.2 $\mathrm{m}$ above the interpreted permafrost depth based on the direct measurements. However, this apparent inconsistency is minor taking the vertical resolution of the GPR data, which is about $0.1 \mathrm{~m}$, and inherent uncertainties regarding velocity estimation and depth conversion into account. Moreover, the slightly shallower reflectivity in this profile distance range may have a different origin. For profile distances larger than $68 \mathrm{~m}$, the

30 GPR data show relatively weak reflectivity indicating stronger attenuation, which is consistent with the drop/shift in 
The Cryosphere Discuss., https://doi.org/10.5194/tc-2017-97

Manuscript under review for journal The Cryosphere

Discussion started: 15 June 2017

(c) Author(s) 2017. CC BY 3.0 License.

resistivity observed in this area in the ERT model and is interpreted as the existence of an open talik at the top of the field site (Fig. A3). Based on geomorphological features (lake and several palsas) at the foot of the field site, an open talik is likely at the end of the moraine. Observations at the field site and analysis of the soil samples indicate the existence of a typical two-layer system in the active layer with an upper high porous organic layer and a lower less porous mineral layer.

5 The border between the two layers is estimated based on interpolation between the sample locations and using the carbon content as a proxy for identifying the boundary between the two horizons. Based on climatic conditions permafrost is likely to be found on higher locations on the moraine. This permafrost acts as an impervious cap that reduces the recharge to the sub-permafrost aquifer. By stopping vertical movement of water, a perched aquifer is formed at the bottom of the active layer in which water is subsequently routed downslope in the active layer. For the subpermafrost aquifer an expected low

10 value for the hydraulic conductivity of the moraine till suggests little exchange of groundwater at depth, so that very limited flow can be assumed.

\subsection{Tracer Observations}

The plumes of the applied tracer behaved differently at the top and middle locations (Fig. 7). At the top location, an elongated breakthrough curve was observed at sensor Top ${ }_{1.5}$ with a slowly rising breakthrough followed by an abrupt

15 recession limb after August 29 in response to several days of precipitation. The average travel velocity until the peak concentration was $10 \mathrm{~cm} / \mathrm{d}$. At the middle location, an immediate response subsequent tracer application was observed at $\mathrm{Mid}_{1}$. Between August 13-18 the sensor failed but it seems that the concentration was fairly stagnant until August 29 when the concentration dropped rapidly in response to precipitation. Sensor $\mathrm{Mid}_{2}$ reacted vaguely around August 12 and had a more abrupt reaction together with sensors $\mathrm{Mid}_{3}$ and $\mathrm{Mid}_{4}$ on August 28. Sensor $\mathrm{Mid}_{5}$ did not show increase in concentration

20 at any time. For the middle tracer the peaks appear approximately 2 days after heavy rainfall at the end of August.

Based on the sensor responses at August 28 the average travel velocity was $170 \mathrm{~cm} / \mathrm{d}$ (Fig. 7). The difference in migration behaviour at the top and middle locations is mainly due to differences in topography of the permafrost surface that was measured and interpolated based on a $50 \mathrm{~cm}$ grid at the two tracer sites. At the top location, the surface was homogeneous that allowed for flow and tracer transport predominantly in the direction of the slope. On the middle location, the permafrost

25 topography was more heterogeneous with local depressions and channels implying a more non-uniform flow pattern (Fig. 8a). The difference in the surface configurations is influencing the shape of the plume as determined from the soil coring (Fig. 8b). For the top location, the tracer moved along the slope and overall formed an elongated and coherent plume while a more lateral-dominated transport is observed at the middle location. The heterogeneity of the permafrost surface created storage capacity in local depressions. In these depressions, the concentration decreased as they were slowly depleted

30 by tracer but as new tracer from the application point entered the depressions again after rainfall the concentration increased as observed between August 21 and 27. 
The Cryosphere Discuss., https://doi.org/10.5194/tc-2017-97

Manuscript under review for journal The Cryosphere

Discussion started: 15 June 2017

(c) Author(s) 2017. CC BY 3.0 License.

\subsection{Modelling Results}

Based on the conceptual model described above, a two-dimensional numerical model is developed for the site (Fig. 6). The outline of the frozen part of the ground is not resolved as a sharp boundary by the employed ERT approach. The $1000 \Omega \mathrm{m}$ isocline of the ERT was used to define the outline of the frozen body, which is excluded from the model domain. At the edges of the parallel-running profile, the perpendicular ERT profiles were used to construct the boundary between frozen and unfrozen ground at depth. The combined knowledge from the stick probing and the GPR profile was used to construct the depth to the base of the active layer, and the interpolated results from the soil samples were used to establish the boundary between organic and mineral soil. Further, temporal variations in the active layer depth are not considered as observations have shown that changes in the active layer depth are modest and on average $3.5 \mathrm{~cm}$ between August 4 and August 21

10 (Fig. 4). The observations suggest that maximum active layer depth is reached at the beginning of August confirming previous results by Humlum (1998). Back-freezing starts at exposed positions and depressions in the permafrost. For a field site with similar seasonal temperature variations, Boike et al. (1998) found variations in active layer depth between mid-July and mid-September to be less than $20 \%$, which corresponds to $10 \mathrm{~cm}$ in the present case. Nevertheless, significant changes occurred close to the open talik where the depth changed $27 \mathrm{~cm}$ over 17 days (Fig. 4).

15 An irregular mesh was defined for the model domain ranging from $0.1 \mathrm{~m}$ for the active layer to about $2 \mathrm{~m}$ for the subpermafrost aquifer (Fig. 6). The simulation period was constrained to the summer period, starting June 1 (Day 1) and ending October 1 (Day 122), during which period flow is active in the active layer. The time step was set to 2 hours, resulting in 1464 time steps. The first ten days served as a spin-up period. Initial conditions for June 1 were assumed to represent dry conditions and were thus set to permanent wilting point. However, subsequent infiltration of meltwater from the snowmelt

20 brought the water content close to saturation implying that the assumptions regarding the initial conditions were not of significance. Fully saturated conditions were assumed in the sub-permafrost aquifer.

The model was calibrated against observations of volumetric water content assuming that sensors with a lateral offset also represented the flow conditions in the transect. The calibration period was August 6 until September 24, where a decrease of soil temperature in the active layer was identified thus making frozen conditions possible. The root mean square error (RMSE) was used as an overall performance criterion:

$R M S E=\sqrt{\frac{1}{N} \sum_{i=1}^{N}\left(O B S_{i}-S I M_{i}\right)^{2}}=M E^{2}+S T D^{2}$

Calibration was performed in two steps. First a manual stepwise calibration was carried out to obtain values for interception of rainfall by vegetation, fraction of melting snow infiltrating at the start of the simulation period, and the dynamic viscosity 
The Cryosphere Discuss., https://doi.org/10.5194/tc-2017-97

Manuscript under review for journal The Cryosphere

Discussion started: 15 June 2017

(c) Author(s) 2017. CC BY 3.0 License.

of water. In a consecutive step automated calibration using PEST (Doherty, 2016) was carried out where the parameters porosity and saturated hydraulic conductivity were individually calibrated for three different soil types. Initial values (Table 1) were specified according to the laboratory measurements.

The manual calibration showed that a higher interception factor and lower snowmelt infiltration generally improve the model performance. However, an interception factor above 0.2 deteriorates the dynamic behaviour of the water content in the active layer drastically, thus a value of 0.2 was used. The infiltration fraction of snow was set to 0.8 , which is a rather high value. However, this parameter also partly accounts for water released upon thawing of the active layer and might not necessarily represent the actual infiltration of snowmelt water. The duration of snowmelt showed only limited sensitivity. The dynamic viscosity has large influence on the dynamics of the water content and best results were obtained for a viscosity at

10 temperature $10^{\circ} \mathrm{C}$.

The automated calibration of the mineral layer resulted in high values for porosity and hydraulic conductivity that exceeded the values obtained from measurements on soil samples and higher than expected for a sand-silt sediment type. The resulting parameter values used in the model are listed in Table A1. The calibration resulted in a RMS of 0.175.

The calibration results are shown in Figure 9. For both the top and the bottom locations the simulated volumetric water

15 content is mostly in between the observed water contents at lateral offset. Shortcomings in the model performance can be attributed to four causes:

1. The position of the sensor relative to the active layer may vary from location to location. Furthermore, the depth of the active layer may change. As the water table follows the frost table (Ireson et al., 2012) this can lead to divergent sensor readings.

20 2. For sub-arctic hillslopes the soil conditions are subject to high heterogeneity including the presence of preferential flow pathways (Carey and Woo, 2001). This leads to a high variability in soil variables and parameters even over very short distances, which is not accounted for in the model.

3. Field observations have documented that water flow on the top of the permafrost table is subject to local threedimensional effects, which cannot be accounted for in a two-dimensional cross-sectional model.

25 4. All temperature dependent effects are ignored; this does not only include variations in the active layer depth, but also effects such as cryo-suction and changing viscosity.

The calibrated model was validated against breakthrough curves of the inert tracer (Fig. 7). The measured values for bulk electrical conductivity $\sigma_{\mathrm{b}}$ were converted to electrical conductivity of the pore water $\sigma_{\mathrm{e}}$ based on the relation developed by Hilhorst (2000):

30

$\sigma_{e}=\frac{\theta}{\theta_{S}} \frac{80.3-0.37 \cdot\left(T_{S o i l}-20\right)}{\varepsilon_{b}-\varepsilon_{\sigma_{b=0}}} \sigma_{b}$ 
The Cryosphere Discuss., https://doi.org/10.5194/tc-2017-97

Manuscript under review for journal The Cryosphere

Discussion started: 15 June 2017

(c) Author(s) 2017. CC BY 3.0 License.

where $\theta$ and $\theta_{\mathrm{S}}$ are water content and water content at saturation, respectively, and $\varepsilon_{b}$ and $\varepsilon_{b, \sigma=0}$ are the dielectric permittivity of the bulk soil and an offset term, respectively, where the latter is set to a value of 4.1 (Hilhorst, 2000). $\sigma_{e}$ is then converted to concentrations c using the relation

$5 \boldsymbol{c}=\boldsymbol{k}_{E C} \cdot \sigma_{e}$

with $k_{E C}$ is a conversion factor, normally assumed to be 0.7 (Walton, 1989).

The model provides reasonable simulations of the tracer breakthroughs particularly in terms of arrival correct times. For both

10 sensors $\mathrm{Mid}_{2}$ and $\mathrm{Mid}_{5}$ a passing of the plume is simulated but not observed, while for $\mathrm{Mid}_{3}$ and $\mathrm{Mid}_{4}$ simulations are aligned with observations revealing that the tracer passed after a lag time of approximately 23 days. At the top location, the model overestimates the tracer velocity, which may be due to the neglect of dynamics in the active layer depth.

\section{Discussion}

\subsection{Hydraulic behaviour}

15 The open taliks within the investigated field site exist due to the presence of non-frozen water maintaining above-freezing temperature at the wetland throughout most of the year. The breaking slope at this position leads to high snow accumulation in the winter due to shielding from northerly dominated wind during the winter months. The snow provides isolation of the underlying ground from low air temperature.

The talik creates thermal and hydrological connection between sub- and supra-permafrost water. Hydraulic head observations (not shown) indicate that the flux in the open talik fluctuates between upward and downward directions and thus it can act as both a source and a sink for water in the active layer. This bimodal flow behaviour implies that travel times can be short for water flowing in the active layer and long for water flowing in the sub-permafrost aquifer. This is in accordance with the findings by Frampton et al. (2012).

The change of flow direction at the open talik also impacts the dynamics of temperature, thus creating a high variability of

25 the extent of frozen ground at the border of the open talik. This is reflected in the change of the active layer depth of $27 \mathrm{~cm}$ at this location between August 4 to August 21, by far exceeding the average change in the active layer depth $(3.5 \mathrm{~cm})$. This phenomenon was also observed by Sjöberg et al. (2016). 
The Cryosphere Discuss., https://doi.org/10.5194/tc-2017-97

Manuscript under review for journal The Cryosphere

Discussion started: 15 June 2017

(c) Author(s) 2017. CC BY 3.0 License.

\subsection{Solute transport in the Active Layer}

The observed tracer plumes and breakthrough curves show how the water movement in the active layer is occurring: Irregular topography of the permafrost table, as observed particularly at the middle location increases the storage volume and can delay the transport by storing water in local depressions that are only in the order of millimetres to centimetres. The effect observed here is conceptually similar to the observations on larger scale as described by Connon et al. (2015), who focused on the interconnectivity of wetlands. The flow on the top of the permafrost follows a fill and spill behaviour that is similar to the processes occurring on hillslopes with bedrocks topography (Wright et al., 2009). Both field observations and model simulations show that the mobilization is controlled by precipitation events. Only if recharge exceeds a certain threshold allowing for built-up of a saturated zone at the base of the active layer that interconnects the local depressions, rapid flow is possible.

From the model simulations, the temporal variation in mean flow velocity can be obtained. As shown in Figure 10 the velocity varies during the summer months in response to the dynamic recharge. High velocities occur at the beginning of the summer season in response to snowmelt. During mid-summer rather low velocities prevail due to little rainfall and high evapotranspiration. Towards the end of August and in September, the velocity increases and remains high in response to

15 precipitation events. A similar pattern was found for the flux across a generic seepage face in a generic model (Frampton et al., 2012) and for river discharge measurement in artic catchments (Holmes et al., 2011) with nitrate transport in rivers happening during snowmelt and heavy rainstorms (McNamara et al., 2008). The accelerated water flow in August is verified by the breakthrough curves showing a rapid decreasing limb. The simulations suggest a similar effect to occur at the beginning of summer in response to large amounts of water from snowmelt. However, given that the dynamics of the active

20 layer are not represented in the model and no observations exist for this period this effect as simulated by the model cannot be verified. However, with only a small area available for flow and high input of water from melting snow, rapid movement of water in the upper zone of the active layer is likely to occur. The velocity by which the active layer thaws controls thereby where the rapid movement occurs: If the melting occurs slowly, water cannot percolate and is therefore transported as surface runoff; if the active layer thaws rapidly, the water table falls below ground and flow occurs in the upper zone of the active layer. Quinton and Baltzer (2012) showed that the transition of the water table from above surface to below surface occurs rapidly as the water table follows the frost table.

In the model the highest flow velocities occur in the emerging saturated bottom of the active layer with velocities exceeding $2.7 \mathrm{~m} / \mathrm{d}$ for a short period after an intense rainfall event. Flow velocities above the saturation layer are much lower, and thus, the simulated plume shows a more rapid movement at the base and a larger spread compared to the shallower layers. Although this is difficult to verify with the collected data, differences in travel times between sensors $\mathrm{Mid}_{2}$ and $\mathrm{Mid}_{4}($ both shallow) and $\mathrm{Mid}_{1}$ and $\mathrm{Mid}_{3}$ (both at the base of the active layer) suggests that this behaviour also occurs at the field site. 
The Cryosphere Discuss., https://doi.org/10.5194/tc-2017-97

Manuscript under review for journal The Cryosphere

Discussion started: 15 June 2017

(c) Author(s) 2017. CC BY 3.0 License.

Thus the flow velocity is variable in three dimensions: Vertical variations in the velocity are caused not only by variations in porosity and permeability over depth (Quinton et al., 2008), humification (Letts et al., 2000) and diplotelmic flow (Jessen et al., 2014) but are also related to the existence of a saturated layer at the bottom of the active layer. Lateral alterations of the velocity arise due to a network of water paths that is controlled by the micro-topography of the permafrost table (Atchley et 5 al., 2015).

In the current model set up velocities in the active layer vary between $0.1 \mathrm{~cm} / \mathrm{d}$ and $270 \mathrm{~cm} / \mathrm{d}$. Both values represent extreme cases that exist only for short periods of time. The migration of a solute eminently depends on the location and time at which it is applied. Nitrate release from thawing permafrost will take place at the bottom of the active layer and will occur during the peak of thaw in August (Elberling et al., 2010). Both the location and the timing facilitate rapid movement of the nitrate

10 before freezing conditions stop the movement of water and solutes.

By averaging only over the summer time and assuming 94 days of thawed conditions an average velocity of $0.15 \mathrm{~m} / \mathrm{d}$ is calculated corresponding to $14 \mathrm{~m} / \mathrm{yr}$. This value applies to the specific field site, which is characterized by a steep topographic slope of $0.2 \%$ and therefore a high hydraulic head gradient.

\section{Conclusion}

15 The present study combined field and laboratory measurements with a two-dimensional numerical model to investigate the fate of solute in the active layer of a slope in a discontinuous permafrost area. Model simulations were calibrated against measurements of soil water content and validated against observed breakthrough curves of an applied conservative tracer. Shortcomings in the model performance can be attributed to missing thermal effects and three-dimensional occurrences, such as high heterogeneity of the soil parameters and lateral flow of water. Although the simplification of the natural conditions creates high uncertainty of the details of model results, the conceptually reasonable simulation of the tracer movement suggests that the model is a valuable tool for simulation of the overall conditions at the site.

The study shows that the flow velocity in the active layer is directly linked to precipitation events. Since recharge is controlled by snowmelt at the beginning of summer and high precipitation at the end of summer, velocities in the active layer show a similar pattern, with velocities in July and September being twice as high as during the summer. This results in

25 discontinuous movement of the tracer, which is confirmed by observations of the tracer experiment and simulated breakthrough curves. During the period from the beginning of July to the end of August slow or stagnant behaviour is observed while accelerated and rapid movement is observed for September. Further complications occur through changing depth of the active layer, which was not addressed in the present study. This phenomenon can be expected to increase velocities during the snowmelt further due to decreased thickness and potential surface runoff. 
The Cryosphere Discuss., https://doi.org/10.5194/tc-2017-97

Manuscript under review for journal The Cryosphere

Discussion started: 15 June 2017

(c) Author(s) 2017. CC BY 3.0 License.

These findings imply that nitrate, which becomes available through winter decomposition (i.e. close to the surface) follows different transport paths and therefore velocities than nitrate released from permafrost melt in the summer (i.e.at the base of the active layer). Nitrate, located at the base of the active layer and therefore frozen during snowmelt, may have travelled the entire slope by the end of the summer, when the active layer has thawed and the water content is high. The model results suggest that the travel distances for a summer season may up to $14 \mathrm{~m}$ or even higher if the solutes are transported through preferential flow paths.

The direction and velocity of the flow and thus solutes, are controlled by the topography of the frozen ground. This study confirms that a complex topography with ridges and depressions leads to lateral flow and retention in small depressions until an increase of the water table allows for overspill of the tracer. Observed changes in flow direction in the proximity of an open talik imply that in discontinuous permafrost regions these open taliks can serve as a sink for nitrogen coming from higher elevation upstream regions.

With increasing temperature due to climate change leading to more thawing of the uppermost permafrost layer during summer and with expected future drier summers and wetter autumns, the observations in this study suggest an acceleration of nutrient transport in the active layer on slopes underlain by permafrost.

\section{Acknowledgements}

The Danish National Research Foundation is acknowledged for supporting the Center for Permafrost (CENPERM DNRF100).

\section{References}

Atchley, A. L., Painter, S. L., Harp, D. R., Coon, E. T., Wilson, C. J., Liljedahl, A. K., and Romanovsky, V. E.: Using field observations to inform thermal hydrology models of permafrost dynamics with ATS (v0.83), Geoscientific Model Development, 8, 2701-2722, 10.5194/gmd-8-2701-2015, 2015.

Bense, V. F., Ferguson, G., and Kooi, H.: Evolution of shallow groundwater flow systems in areas of degrading permafrost, Geophysical Research Letters, 36, 10.1029/2009gl039225, 2009.

Bense, V. F., Kooi, H., Ferguson, G., and Read, T.: Permafrost degradation as a control on hydrogeological regime shifts in a warming climate, Journal of Geophysical Research: Earth Surface, 117, n/a-n/a, 10.1029/2011jf002143, 2012.

Blok, D., Elberling, B., and Michelsen, A.: Initial Stages of Tundra Shrub Litter Decomposition May Be Accelerated by Deeper Winter Snow But Slowed Down by Spring Warming, Ecosystems, 19, 155-169, 10.1007/s10021-015-99243, 2016.

Blume, H.-P., Stahr, K., and Leinweber, P.: Bodenkundliches Praktikum: Eine Einführung in pedologisches Arbeiten für Ökologen, insbesondere Land- und Forstwirte, und für Geowissenschaftler, Spektrum Akademischer Verlag: Heidelberg, 2011.

Boike, J., Roth, K., and Overduin, P. P.: Thermal and hydrologic dynamics of the active layer at a continuous permafrost site (Taymyr Peninsula, Siberia), Water Resources Research, 34, 355-363, 10.1029/97wr03498, 1998. 
The Cryosphere Discuss., https://doi.org/10.5194/tc-2017-97

Manuscript under review for journal The Cryosphere

Discussion started: 15 June 2017

(c) Author(s) 2017. CC BY 3.0 License.
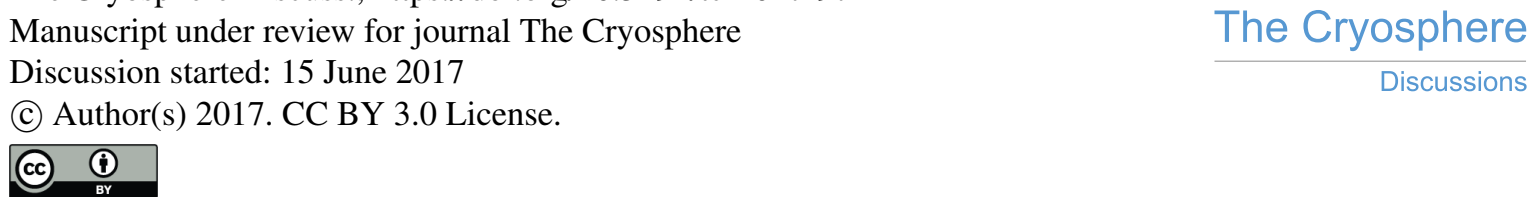

Bonnaventure, P. P., and Lamoureux, S. F.: The active layer: A conceptual review of monitoring, modelling techniques and changes in a warming climate, Progress in Physical Geography, 37, 352-376, 10.1177/0309133313478314, 2013.

Bring, A., Fedorova, I., Dibike, Y., Hinzman, L., Mård, J., Mernild, S., Prowse, T., Semenova, O., Stuefer, S., and Woo, M. K.: Arctic terrestrial hydrology: A synthesis of processes, regional effects and research challenges, Journal of Geophysical Research: Biogeosciences, 2016.

Carey, S. K., and Woo, M.-K.: Spatial variability of hillslope water balance, wolf creek basin, subarctic yukon, Hydrological Processes, 15, 3113-3132, 10.1002/hyp.319, 2001.

Connon, R. F., Quinton, W. L., Craig, J. R., Hanisch, J., and Sonnentag, O.: The hydrology of interconnected bog complexes in discontinuous permafrost terrains, Hydrological Processes, 29, 3831-3847, 10.1002/hyp.10604, 2015.

10 D'Imperio, L., Nielsen, C. S., Westergaard-Nielsen, A., Michelsen, A., and Elberling, B.: Methane oxidation in contrasting soil types: responses to experimental warming with implication for landscape-integrated CH4 budget, Glob Chang Biol, 23, 966-976, 10.1111/gcb.13400, 2017.

DeWalle, D. R., and Rango, A.: Principles of Snow Hydrology, Cambridge University Press, -- pp., 2008.

Doherty, J.: PEST: Model-Independent Parameter Estimation User Manual Part I: PEST, SENSAN and Global Optimisers, Watermark Numerical Computing, 6th edition, 2016.

Daanen, R. P., Ingeman-Nielsen, T., Marchenko, S. S., Romanovsky, V. E., Foged, N., Stendel, M., Christensen, J. H., and Hornbech Svensen, K.: Permafrost degradation risk zone assessment using simulation models, The Cryosphere Discussions, 5, 1021-1053, 10.5194/tcd-5-1021-2011, 2011.

Elberling, B., Christiansen, H. H., and Hansen, B. U.: High nitrous oxide production from thawing permafrost, Nature Geoscience, 3, 332-335, 10.1038/ngeo803, 2010.

Frampton, A., Painter, S., Lyon, S. W., and Destouni, G.: Non-isothermal, three-phase simulations of near-surface flows in a model permafrost system under seasonal variability and climate change, Journal of Hydrology, 403, 352-359, 10.1016/j.jhydrol.2011.04.010, 2011.

Frampton, A., Painter, S. L., and Destouni, G.: Permafrost degradation and subsurface-flow changes caused by surface warming trends, Hydrogeology Journal, 21, 271-280, 10.1007/s10040-012-0938-z, 2012.

Frampton, A., and Destouni, G.: Impact of degrading permafrost on subsurface solute transport pathways and travel times, Water Resources Research, 51, 7680-7701, 2015.

Frey, K. E., and McClelland, J. W.: Impacts of permafrost degradation on arctic river biogeochemistry, Hydrological Processes, 23, 169-182, 10.1002/hyp.7196, 2009.

30 Gacitúa, G., Tamstorf, M. P., Kristiansen, S. M., and Uribe, J. A.: Estimations of moisture content in the active layer in an Arctic ecosystem by using ground-penetrating radar profiling, Journal of Applied Geophysics, 79, 100-106, 10.1016/j.jappgeo.2011.12.003, 2012.

Hansen, B. U., Elberling, B., Hollesen, J., and Nielsen, N.: Naturen Omkring Arktisk Station: Vejret og klimaet, in: Arktisk Station 1906-2006, edited by: Bruun, L., Københavns Universitet, København, 44-57, 2006 a.

Hansen, B. U., Elberling, B., Humlum, O., and Nielsen, N.: Meteorological trends (1991-2004) at Arctic Station, Central West Greenland $\left(69^{\circ} 15^{\prime} \mathrm{N}\right)$ in a 130 years perspective, Geografisk Tidsskrift-Danish Journal of Geography, 106, 45 $55,10.1080 / 00167223.2006 .10649544,2006 b$.

Harms, T. K., and Jones, J. B., Jr.: Thaw depth determines reaction and transport of inorganic nitrogen in valley bottom permafrost soils: Nitrogen cycling in permafrost soils, Glob Chang Biol, 18, 2958-2968, 10.1111/j.13652486.2012.02731.x, 2012.

Harms, T. K., and Ludwig, S. M.: Retention and removal of nitrogen and phosphorus in saturated soils of arctic hillslopes, Biogeochemistry, 127, 291-304, 10.1007/s10533-016-0181-0, 2016.

Hilhorst, M. A.: A pore water conductivity sensor, Soil Science Society of America Journal, 64, 1922-1925, 2000.

Hollesen, J., Buchwal, A., Rachlewicz, G., Hansen, B. U., Hansen, M. O., Stecher, O., and Elberling, B.: Winter warming as an important co-driver for Betula nana growth in western Greenland during the past century, Glob Chang Biol, 21, 2410-2423, 10.1111/gcb.12913, 2015.

Holmes, R. M., McClelland, J. W., Peterson, B. J., Tank, S. E., Bulygina, E., Eglinton, T. I., Gordeev, V. V., Gurtovaya, T. Y., Raymond, P. A., Repeta, D. J., Staples, R., Striegl, R. G., Zhulidov, A. V., and Zimov, S. A.: Seasonal and 
The Cryosphere Discuss., https://doi.org/10.5194/tc-2017-97

Manuscript under review for journal The Cryosphere

Discussion started: 15 June 2017

(c) Author(s) 2017. CC BY 3.0 License.

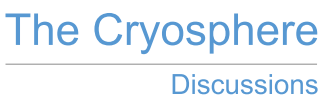

(c) (i)

Annual Fluxes of Nutrients and Organic Matter from Large Rivers to the Arctic Ocean and Surrounding Seas, Estuaries and Coasts, 35, 369-382, 10.1007/s12237-011-9386-6, 2011.

Humlum, O.: Active layer thermal regime 1991-1996 at Qeqertarsuaq, Disko Island, central west Greenland. , Arctic and Alpine Researc 295-305, 1998.

5 IPCC: Climate Change 2014: Impacts, Adaptation, and Vulnerability. Part A: Global and Sectoral Aspects. Contribution of Working Group II to the Fifth Assessment Report of the Intergovernmental Panel on Climate Change : [Field, C.B., V.R. Barros, D.J. Dokken, K.J. Mach, M.D. Mastrandrea, T.E. Bilir, M. Chatterjee, K.L. Ebi, Y.O. Estrada, R.C. Genova, B. Girma, E.S. Kissel, A.N. Levy, S. MacCracken, P.R. Mastrandrea, and L.L. White (eds.)]. , Cambridge University Press, Cambridge, United Kingdom and New York, NY, USA, 1132 pp., 2014.

10 Ireson, A. M., van der Kamp, G., Ferguson, G., Nachshon, U., and Wheater, H. S.: Hydrogeological processes in seasonally frozen northern latitudes: understanding, gaps and challenges, Hydrogeology Journal, 21, 53-66, 10.1007/s10040012-0916-5, 2012.

Ishikava, M.: ERT imaging for frozen ground detection, in: Applied Geophysics in Periglacial Environments., edited by: Hauck, C., and Kneisel, C., Cambridge University Press Cambridge, 109-117, 2008.

Jessen, S., Holmslykke, H. D., Rasmussen, K., Richardt, N., and Holm, P. E.: Hydrology and pore water chemistry in a permafrost wetland, Ilulissat, Greenland, Water Resources Research, 50, 4760-4774, 2014.

Jorgenson, M. T., Romanovsky, V., Harden, J., Shur, Y., O'Donnell, J., Schuur, E. A., and Marchenko, S.: Resilience and vulnerability of permafrost to climate change This article is one of a selection of papers from The Dynamics of Change in Alaska's Boreal Forests: Resilience and Vulnerability in Response to Climate Warming., Canadian Journal of Forest Research, 40, 1219-1236, 2010.

Jørgensen, A. S., and Andreasen, F.: Mapping of permafrost surface using ground-penetrating radar at Kangerlussuaq Airport, western Greenland, Cold Regions Science and Technology, 48, 64-72, 10.1016/j.coldregions.2006.10.007, 2007.

Kursus i arktisk geomorfologi: Godhavn-Områdets geomorfologi,, Copenhagen University, 1978.

Kurylyk, B. L., MacQuarrie, K. T. B., and McKenzie, J. M.: Climate change impacts on groundwater and soil temperatures in cold and temperate regions: Implications, mathematical theory, and emerging simulation tools, Earth-Science Reviews, 138, 313-334, 10.1016/j.earscirev.2014.06.006, 2014.

Letts, M. G., Roulet, N. T., Comer, N. T., Skarupa, M. R., and Verseghy, D. L.: Parametrization of peatland hydraulic properties for the Canadian land surface scheme, Atmosphere-Ocean, 38, 141-160,

$30 \quad 10.1080 / 07055900.2000 .9649643,2000$.

Loke, M. H.: RES2DINVx64 ver. 4.05: Rapid 2-D Resistivity \& IP inversion using the least-squares method., Geotomosoft solutions, Geotomo Software PTY LTD, 2015.

McCutcheon, S. C., Martin, J. L., and Barnwell, T. O. J.: Water Quality in Maidment, Handbook of Hydrology, 113, 1993.

McNamara, J. P., Kane, D. L., Hobbie, J. E., and Kling, G. W.: Hydrologic and biogeochemical controls on the spatial and temporal patterns of nitrogen and phosphorus in the Kuparuk River, arctic Alaska, Hydrological Processes, 22, 3294-3309, 10.1002/hyp.6920, 2008.

Neal, A.: Ground-penetrating radar and its use in sedimentology: principles, problems and progress, Earth-Science Reviews, 66, 261-330, 10.1016/j.earscirev.2004.01.004, 2004.

Pedersen, A. K., Pedersen, G. K., and Larsen, L. M.: Naturen Omkring Arktisk Station: Geologien, in: Arktisk Station 19062006, edited by: Bruun, L., Københavns Universitet, København, 17-33, 2006.

Petrone, K., Buffam, I., and Laudon, H.: Hydrologic and biotic control of nitrogen export during snowmelt: A combined conservative and reactive tracer approach, Water Resources Research, 43, n/a-n/a, 10.1029/2006wr005286, 2007.

Priestley, C. H. B., and Taylor, R.: On the assessment of surface heat flux and evaporation using large-scale parameters., Monthly Weath. Rev,, 100, 81, 1972.

45 Quinton, W. L., Hayashi, M., and Carey, S. K.: Peat hydraulic conductivity in cold regions and its relation to pore size and geometry, Hydrological Processes, 22, 2829-2837, 10.1002/hyp.7027, 2008.

Quinton, W. L., and Baltzer, J. L.: The active-layer hydrology of a peat plateau with thawing permafrost (Scotty Creek, Canada), Hydrogeology Journal, 21, 201-220, 10.1007/s10040-012-0935-2, 2012. 
The Cryosphere Discuss., https://doi.org/10.5194/tc-2017-97

Manuscript under review for journal The Cryosphere

Discussion started: 15 June 2017

(c) Author(s) 2017. CC BY 3.0 License.

Schaeffer, S. M., Sharp, E., Schimel, J. P., and Welker, J. M.: Soil-plant N processes in a High Arctic ecosystem, NW Greenland are altered by long-term experimental warming and higher rainfall, Glob Chang Biol, 19, 3529-3539, 10.1111/gcb.12318, 2013.

Sjöberg, Y., Coon, E., Sannel, K., Britta, A., Pannetier, R., Harp, D., Frampton, A., Painter, S. L., and Lyon, S. W.: Thermal effects of groundwater flow through subarctic fens: A case study based on field observations and numerical modeling, Water Resources Research, 2016.

Tetzlaff, D., Buttle, J., Carey, S. K., McGuire, K., Laudon, H., and Soulsby, C.: Tracer-based assessment of flow paths, storage and runoff generation in northern catchments: a review, Hydrological Processes, 29, 3475-3490, 10.1002/hyp.10412, 2015.

10 Van Genuchten, M. T.: A closed-form equation for predicting the hydraulic conductivity of unsaturated soils, Soil science society of America journal, 44, 892-898, 1980.

Voss, C. I., and Provost, A. M.: SUTRA A Model for Saturated-Unsaturated, Variable-Density Ground-Water Flow with Solute or Energy Transport, US Geological Survey Water Resources Invest Rep 02-4231, 250 pp. US Geological Survey, Reston, 2010.

15 Walton, N. R. G.: Electrical Conductivity and Total Dissolved Solids-What is Their Precise Relationship?, Desalination, 72, 275-292, http://dx.doi.org/10.1016/0011-9164(89)80012-8, 1989.

Woo, M.-K.: Permafrost hydrology, Springer, 2012.

Wright, N., Hayashi, M., and Quinton, W. L.: Spatial and temporal variations in active layer thawing and their implication on runoff generation in peat-covered permafrost terrain, Water Resources Research, 45, 10.1029/2008wr006880, 2009.

Yano, Y., Shaver, G. R., Giblin, A. E., Rastetter, E. B., and Nadelhoffer, K. J.: Nitrogen dynamics in a small arctic watershed retention and downhill movement of $15 \mathrm{~N}, 2010$. 
The Cryosphere Discuss., https://doi.org/10.5194/tc-2017-97

Manuscript under review for journal The Cryosphere

Discussion started: 15 June 2017

(c) Author(s) 2017. CC BY 3.0 License.

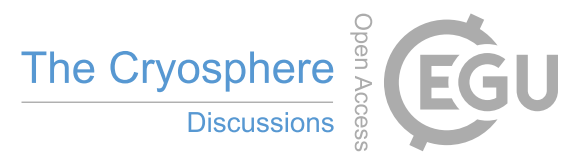

(c) (i)

Table 1: Initial values and ranges for the automated calibration and results of the calibration with estimated parameter and confidence interval (CI).

\begin{tabular}{c|c|ccc|ccc||} 
& Unit & Ini $_{\text {min }}$ & Initial & $\mathbf{I n i}_{\text {max }}$ & $\mathbf{C I}_{\text {low }}$ & Estimated & $\mathbf{C I}_{\text {up }}$ \\
\hline $\mathbf{K}_{\text {org }}$ & $c m / d$ & $6.5 \cdot 10^{-2}$ & $6.5 \cdot 10^{2}$ & $6.5 \cdot 10^{7}$ & 784.6 & 900 & 1033 \\
$\mathbf{K}_{\text {min }}$ & $c m / d$ & $2.8 \cdot 10^{-2}$ & $2.8 \cdot 10^{-2}$ & $2.8 \cdot 10^{7}$ & 1389.2 & 1431 & 1475 \\
$\mathbf{K}_{\text {till }}$ & $c m / d$ & $1.0 \cdot 10^{-2}$ & $1.0 \cdot 10^{-2}$ & $1.0 \cdot 10^{-7}$ & 0.01 & 0.10 & 0.19 \\
$\mathbf{n}_{\text {org }}$ & - & 0.90 & 0.95 & 0.98 & 0.96 & 0.97 & 0.98 \\
$\mathbf{n}_{\text {min }}$ & - & 0.40 & 0.69 & 0.90 & 0.89 & 0.90 & 0.91 \\
$\mathbf{n}_{\text {till }}$ & - & 0.30 & 0.48 & 0.70 & 0.51 & 0.54 & 0.57
\end{tabular}
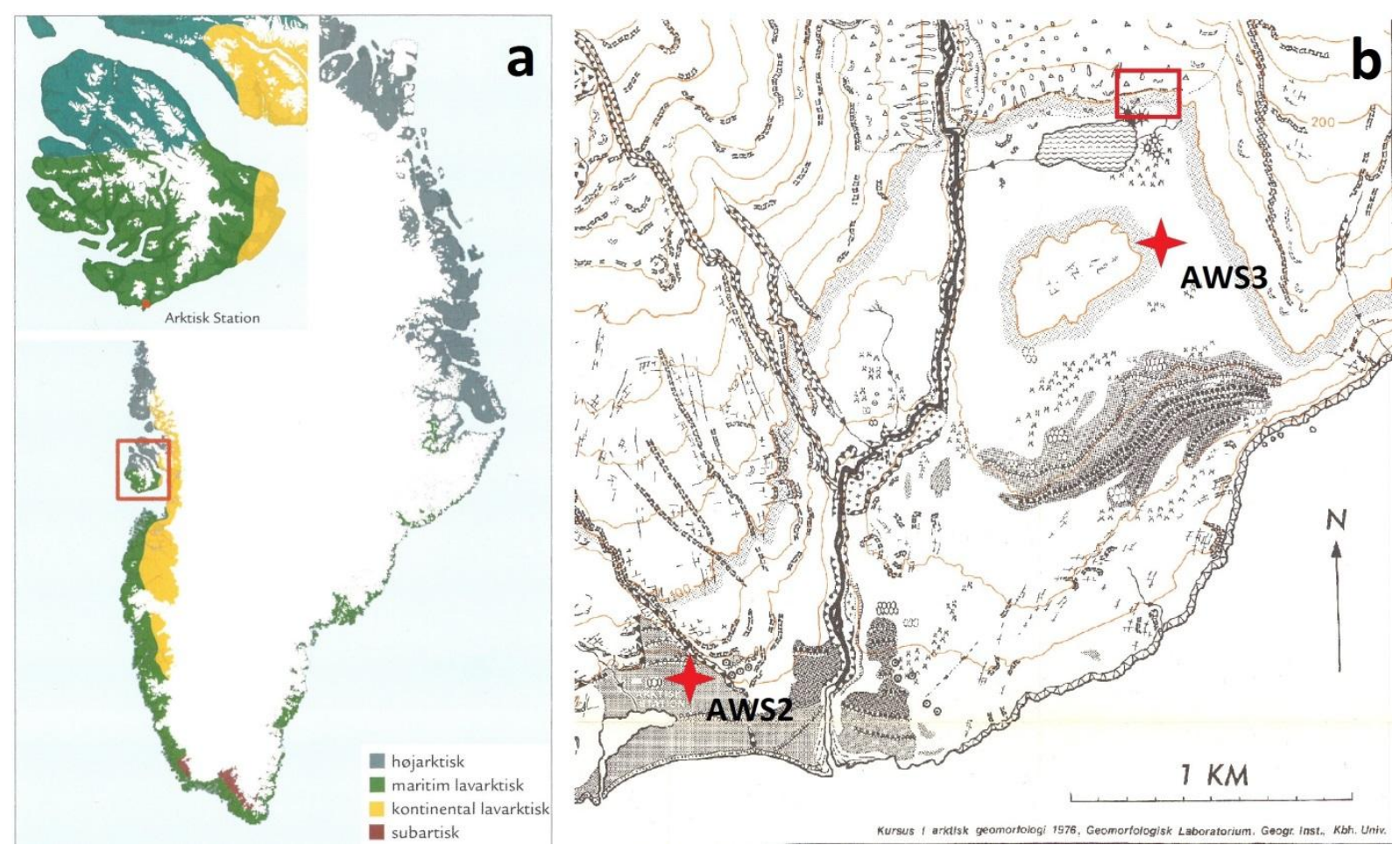

Figure 1:Location of study area. Stars mark the positions of the weather stations and red square indicates the location of the field site. The field site is located on a south-facing slope on a moraine stretching across the valley, south of the field site a wetland and lake is located. Left figure (a) from (Hansen et al., 2006a), right figure (b) from Kursus i arktisk geomorfologi (1978). 
The Cryosphere Discuss., https://doi.org/10.5194/tc-2017-97

Manuscript under review for journal The Cryosphere

Discussion started: 15 June 2017

(c) Author(s) 2017. CC BY 3.0 License.
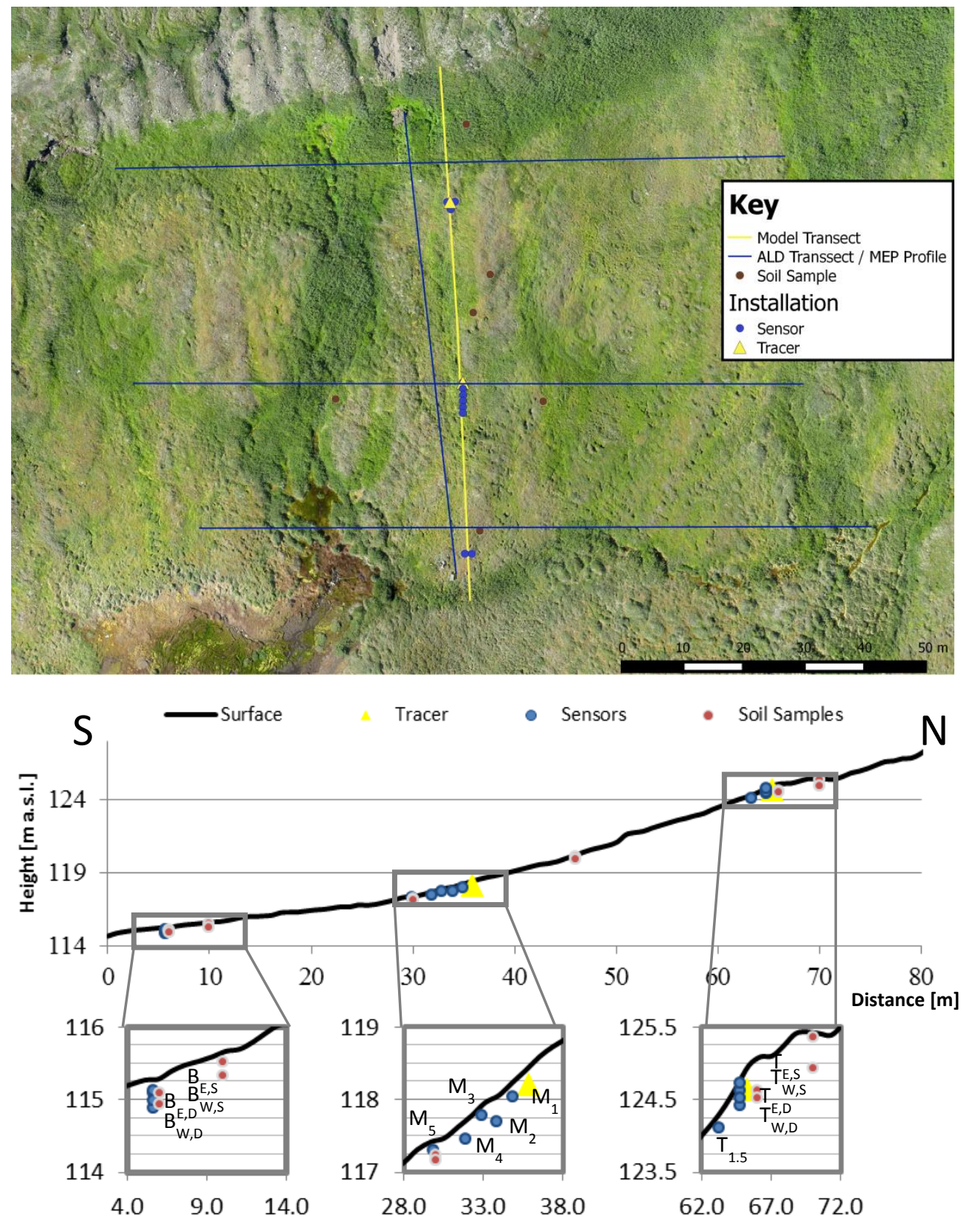

Figure 2: Measurement program at the field site. Lake and wetland located at the south, the moraine continues northward to a height of $153 \mathrm{~m}$ a.s.l. In total 14 soil moisture sensors were installed and 24 soil samples as well as 4 Multi Electrode Profiles (MEP) and Active Layer Depths (ALD) profiles were collected. Tracer was applied at two locations. Profile is $2 x$ exaggerated. Subscripts of the sensors represent location ( $E$ east, $W$ west) and depth ( $S$ shallow, $D$ deep) or the distance in meters from tracer injection site. 
The Cryosphere Discuss., https://doi.org/10.5194/tc-2017-97

Manuscript under review for journal The Cryosphere

Discussion started: 15 June 2017

(c) Author(s) 2017. CC BY 3.0 License.

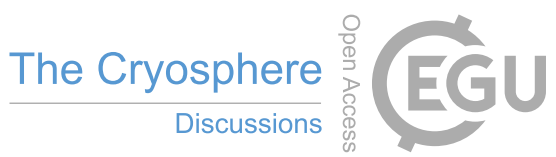

(c) (1)

(a)
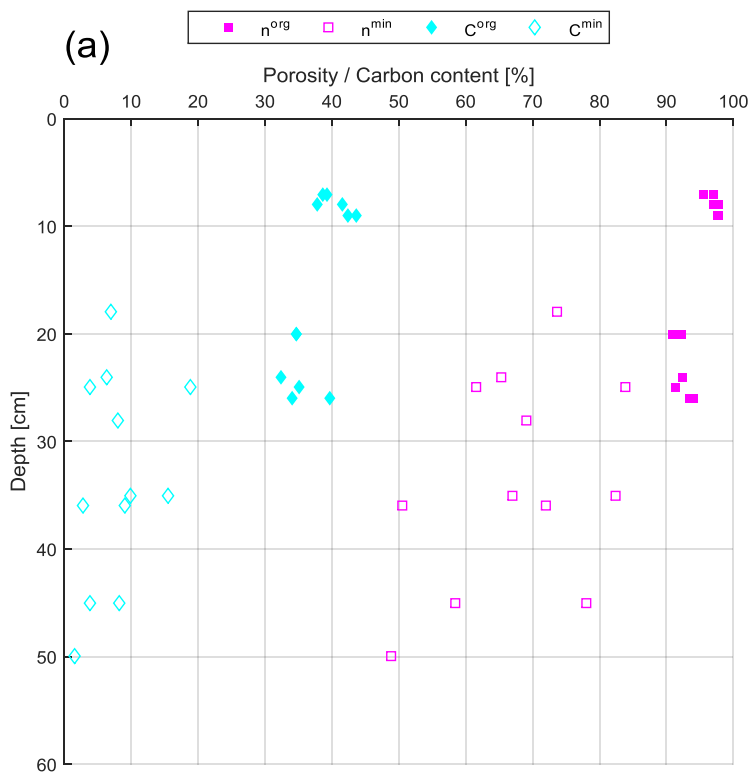

(b)
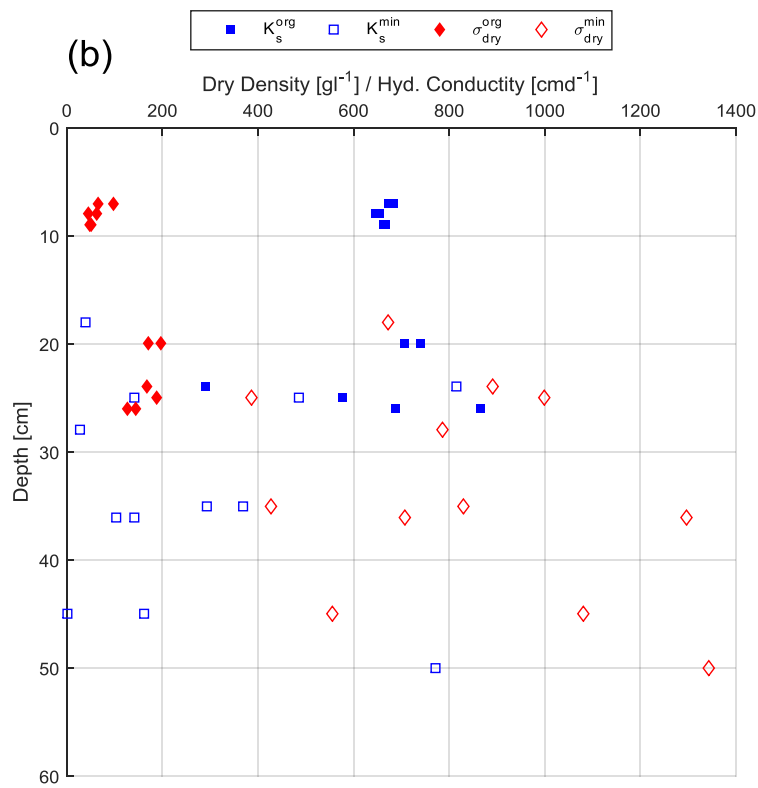

Figure 3: Measured soil parameters as a function of depth show changes between a shallow organic layer (org) and a deep mineral layer (min).

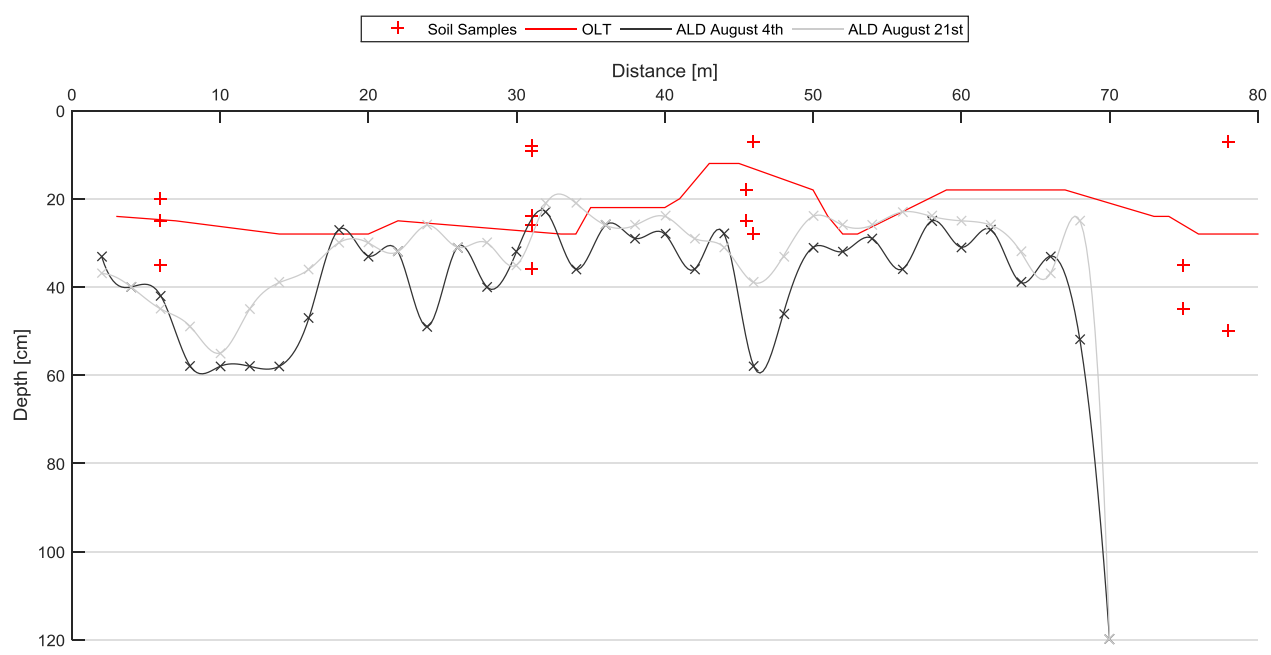

5 Figure 4: Measurements of the active layer depth (ALD) along transect at August 4 and 21 respectively. Average ALD for the two days are $37.8 \mathrm{~cm}$ and $34.2 \mathrm{~cm}$ respectively. The organic layer thickness (OLT) is interpolated based on carbon content measurements of $20 \%$. 
The Cryosphere Discuss., https://doi.org/10.5194/tc-2017-97

Manuscript under review for journal The Cryosphere

Discussion started: 15 June 2017

(c) Author(s) 2017. CC BY 3.0 License.

(a)
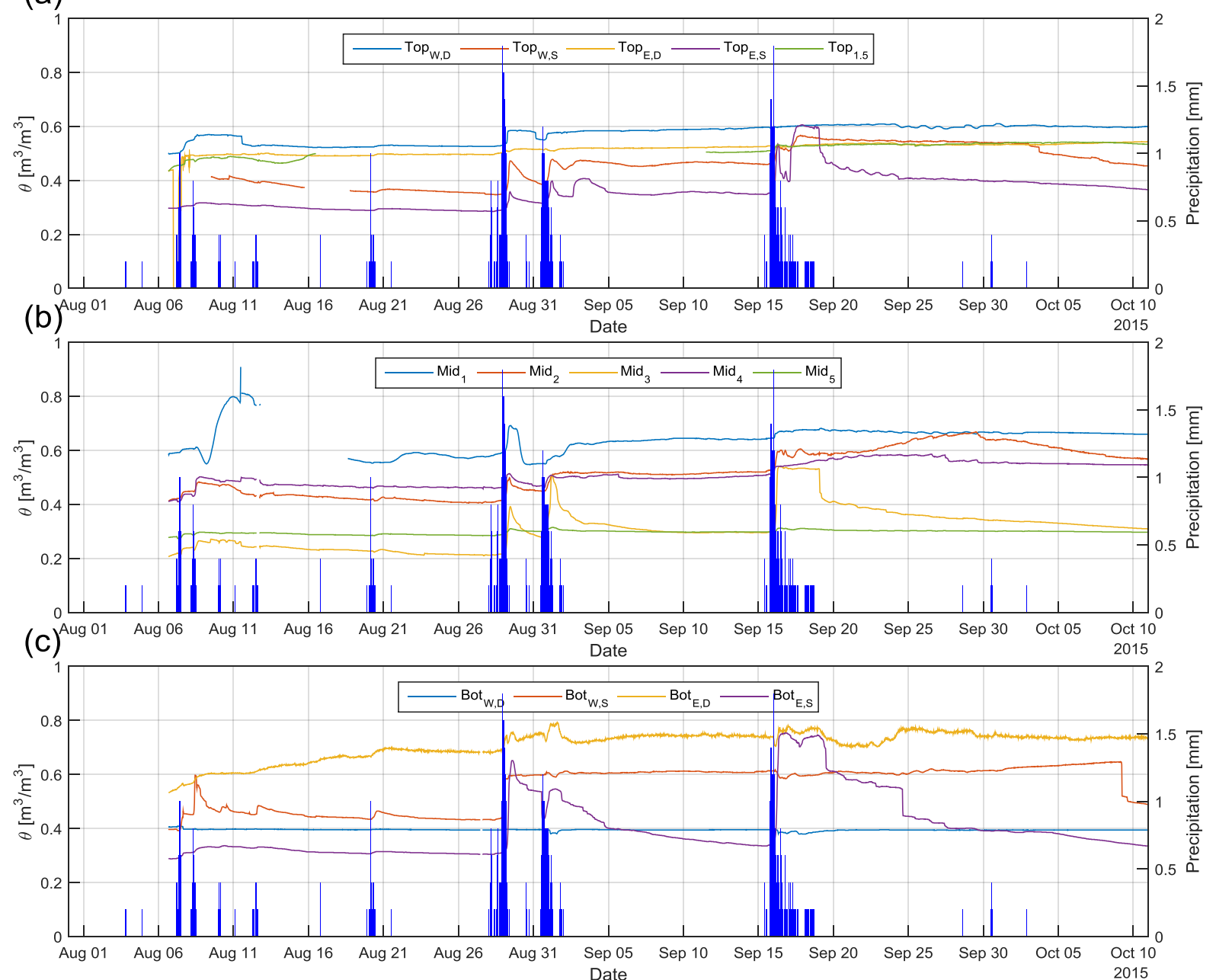

Figure 5: Moisture content variations 14 sensor locations. Plotted in blue is the precipitation (0.5 h interval) at AWS3, which had immediate effect on the soil water content. The passing of the tracer fluid lead to corrupted data for sensor $T_{1.5}$ between August

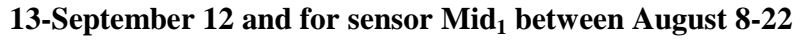


The Cryosphere Discuss., https://doi.org/10.5194/tc-2017-97

Manuscript under review for journal The Cryosphere

Discussion started: 15 June 2017

(c) Author(s) 2017. CC BY 3.0 License.

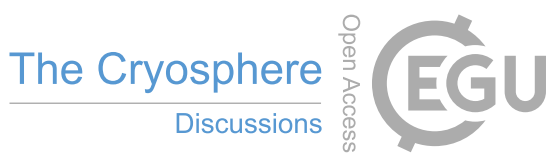

(c)

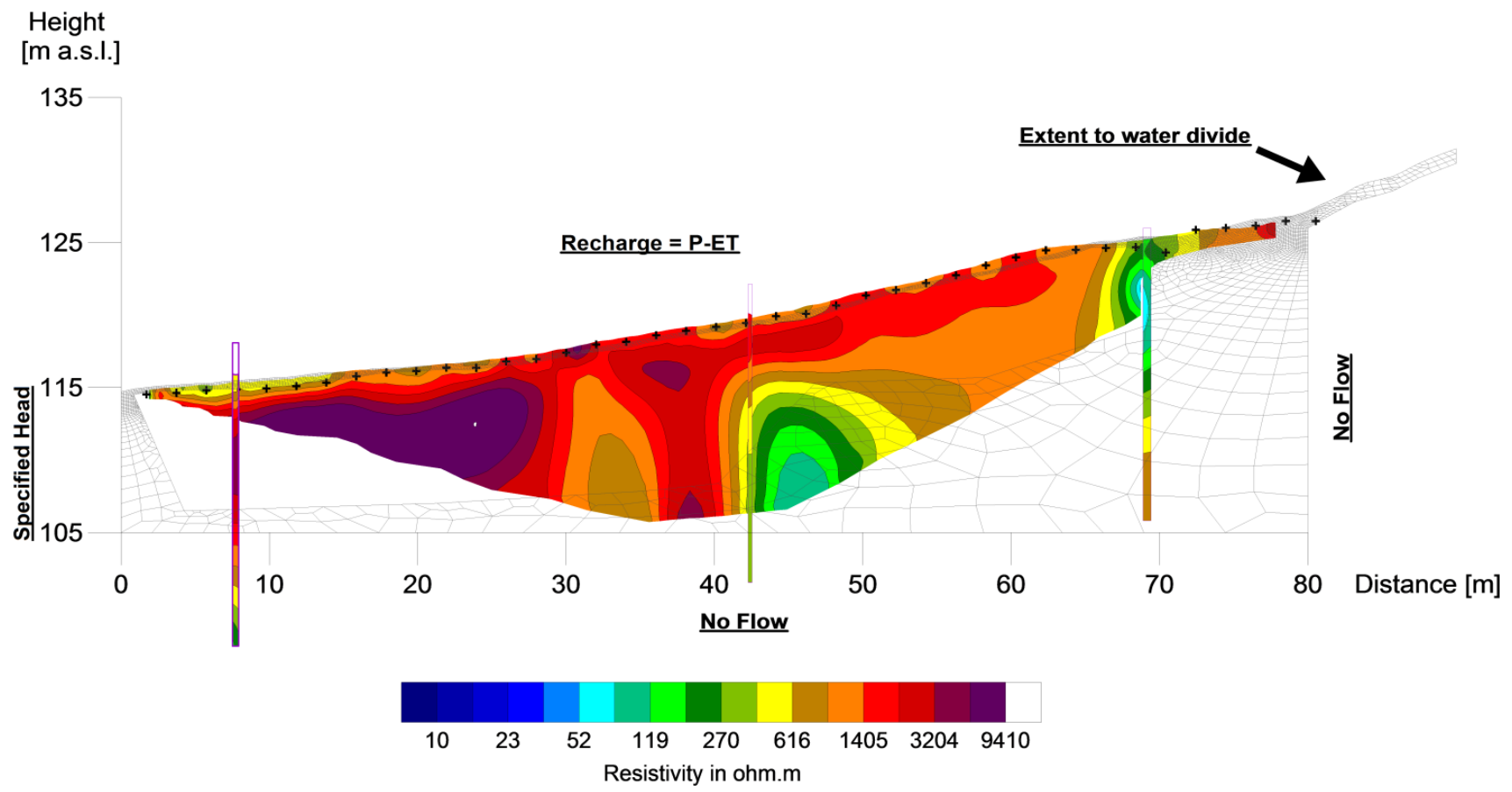

Figure 6: Multi electrode profile (MEP) of the field site. Black crosses show measured active layer depth. Vertical lines show the resistivity of perpendicular profiles at the respective distances. ERT profiles were used to constrain the numerical grid used to model the solute transport at the site. 
The Cryosphere Discuss., https://doi.org/10.5194/tc-2017-97

Manuscript under review for journal The Cryosphere

Discussion started: 15 June 2017

(c) Author(s) 2017. CC BY 3.0 License.
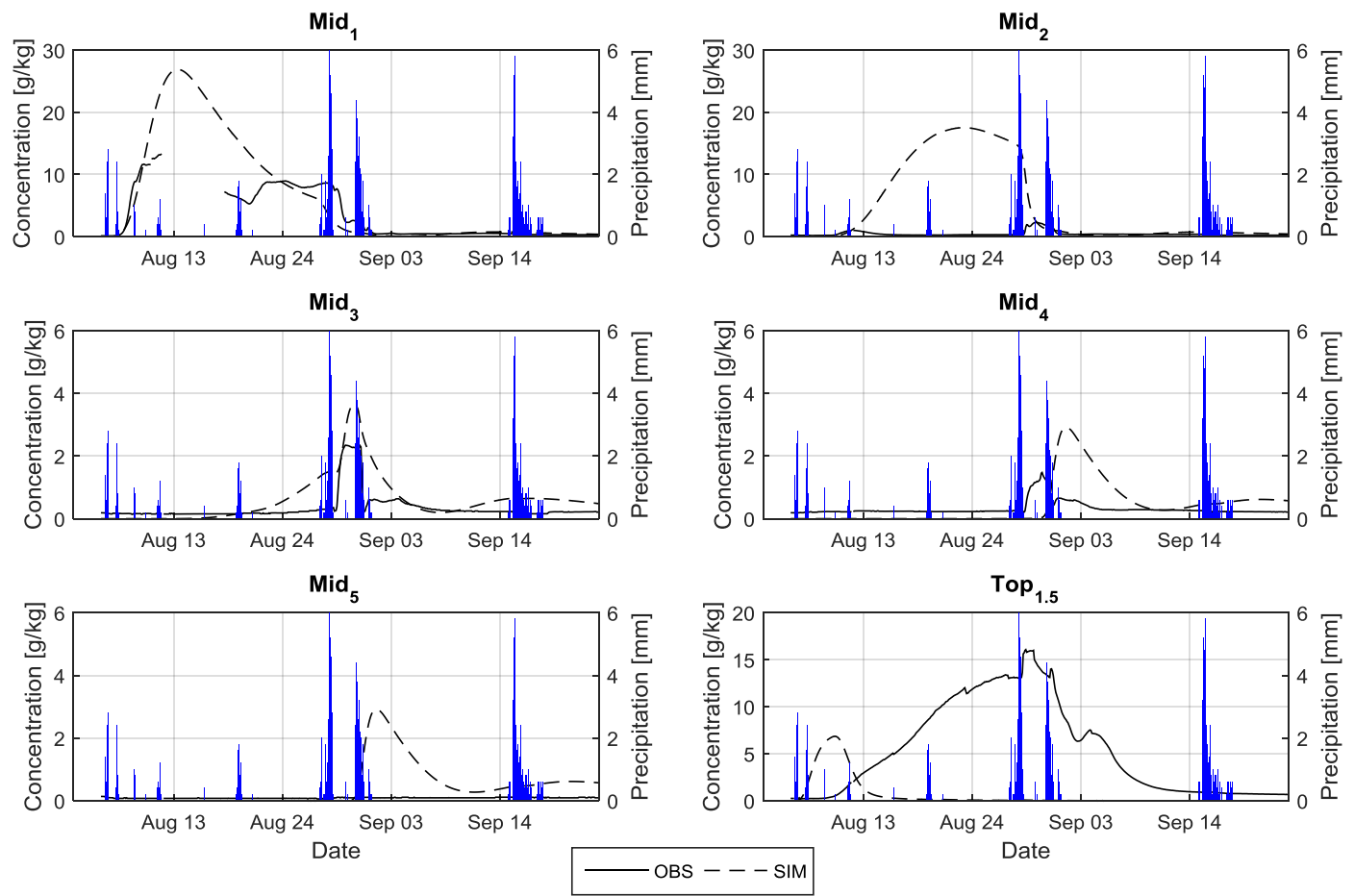

Fig. 7: Observed and simulated breakthrough curves at the different locations. Plotted in blue is the precipitation ( $2 \mathrm{~h}$ interval) at AWS3, which shows direct influence on the observed progression of the tracer. 
The Cryosphere Discuss., https://doi.org/10.5194/tc-2017-97

Manuscript under review for journal The Cryosphere

Discussion started: 15 June 2017

(c) Author(s) 2017. CC BY 3.0 License.

(c) (i)
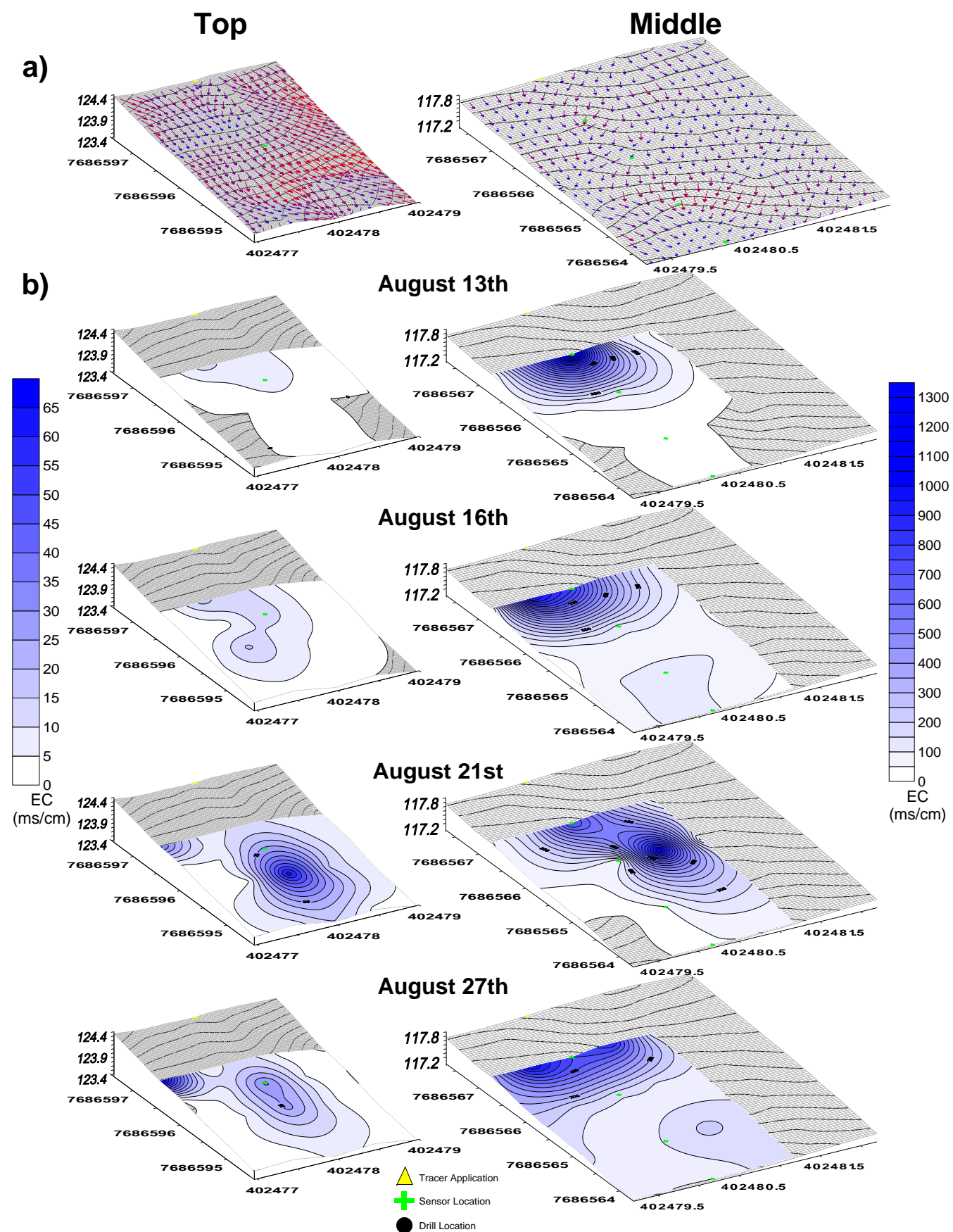

Figure 8: a) Micro-topography of the frost table and resulting flow pattern at the two locations. b) Tracer plumes at the two locations at four dates. 
The Cryosphere Discuss., https://doi.org/10.5194/tc-2017-97

Manuscript under review for journal The Cryosphere

Discussion started: 15 June 2017

(c) Author(s) 2017. CC BY 3.0 License.
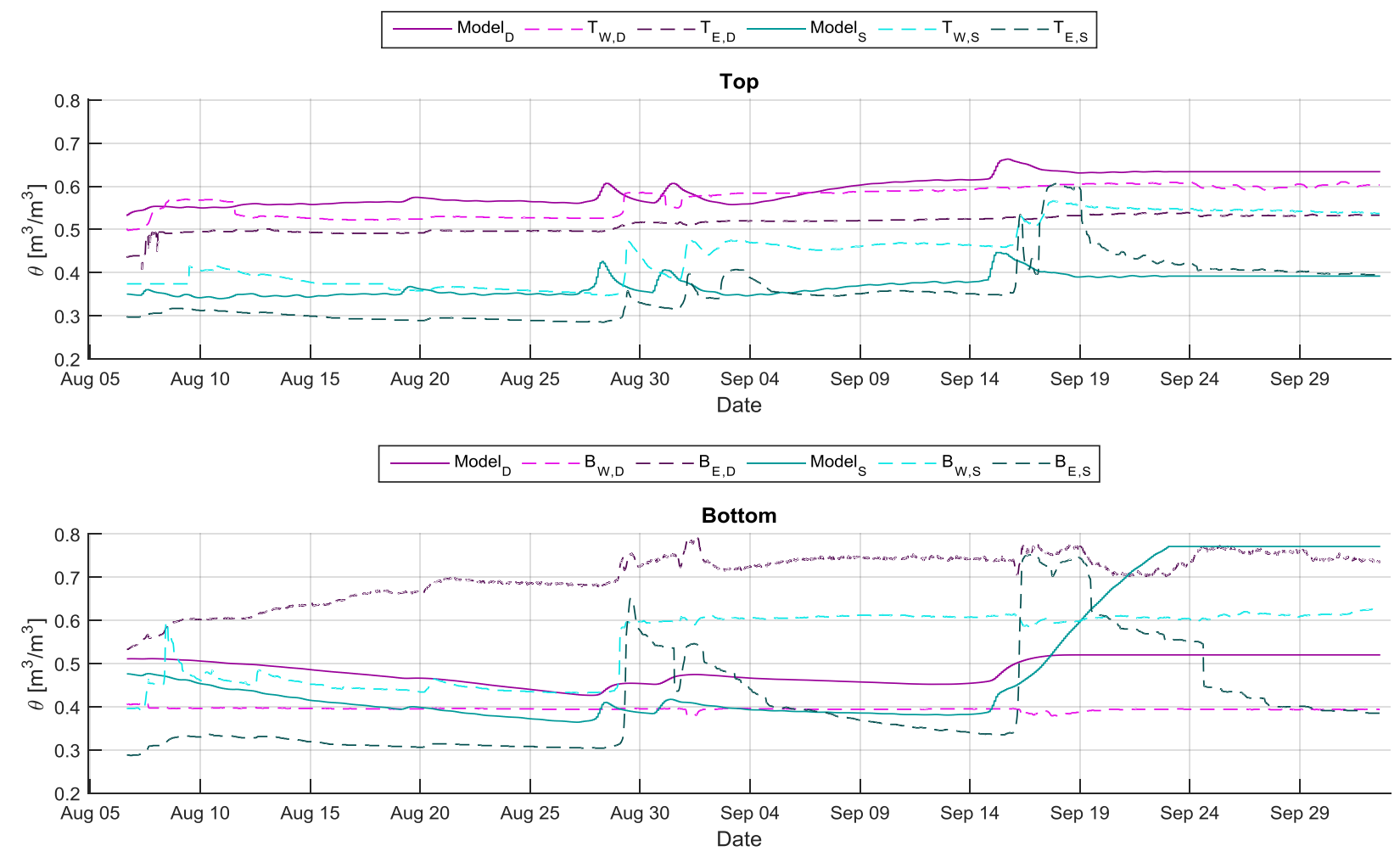

Figure 9: Model simulations of moisture content for shallow (green) and deep (red) depths at the top and bottom locations. Continuous lines represent observed soil moisture east and west of the profile. 
The Cryosphere Discuss., https://doi.org/10.5194/tc-2017-97

Manuscript under review for journal The Cryosphere

Discussion started: 15 June 2017

(c) Author(s) 2017. CC BY 3.0 License.

(c)

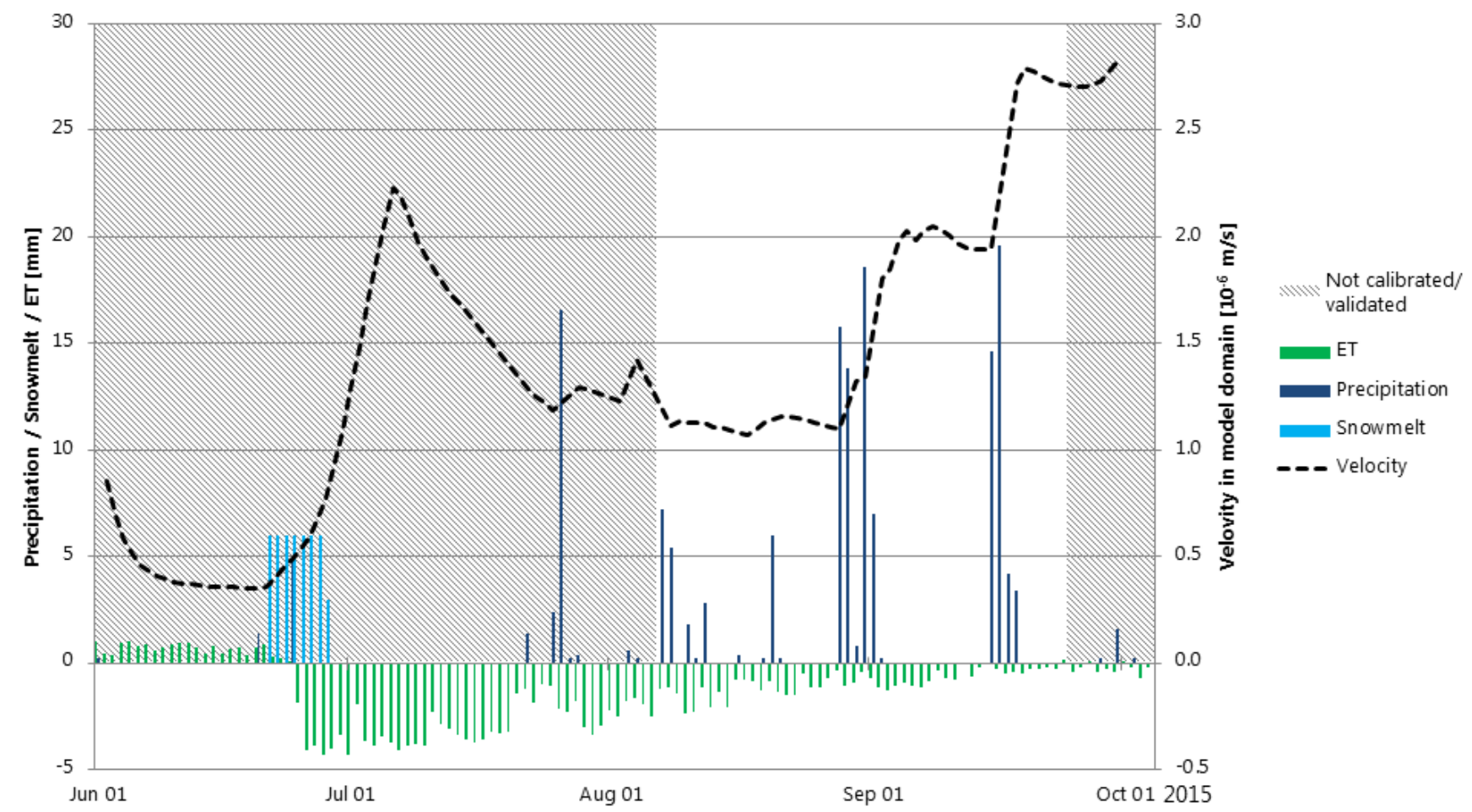

Figure 10: Averaged velocity in the model domain for the simulation period and drivers of the water balance. 
The Cryosphere Discuss., https://doi.org/10.5194/tc-2017-97

Manuscript under review for journal The Cryosphere

Discussion started: 15 June 2017

(c) Author(s) 2017. CC BY 3.0 License.

\section{Appendix A}

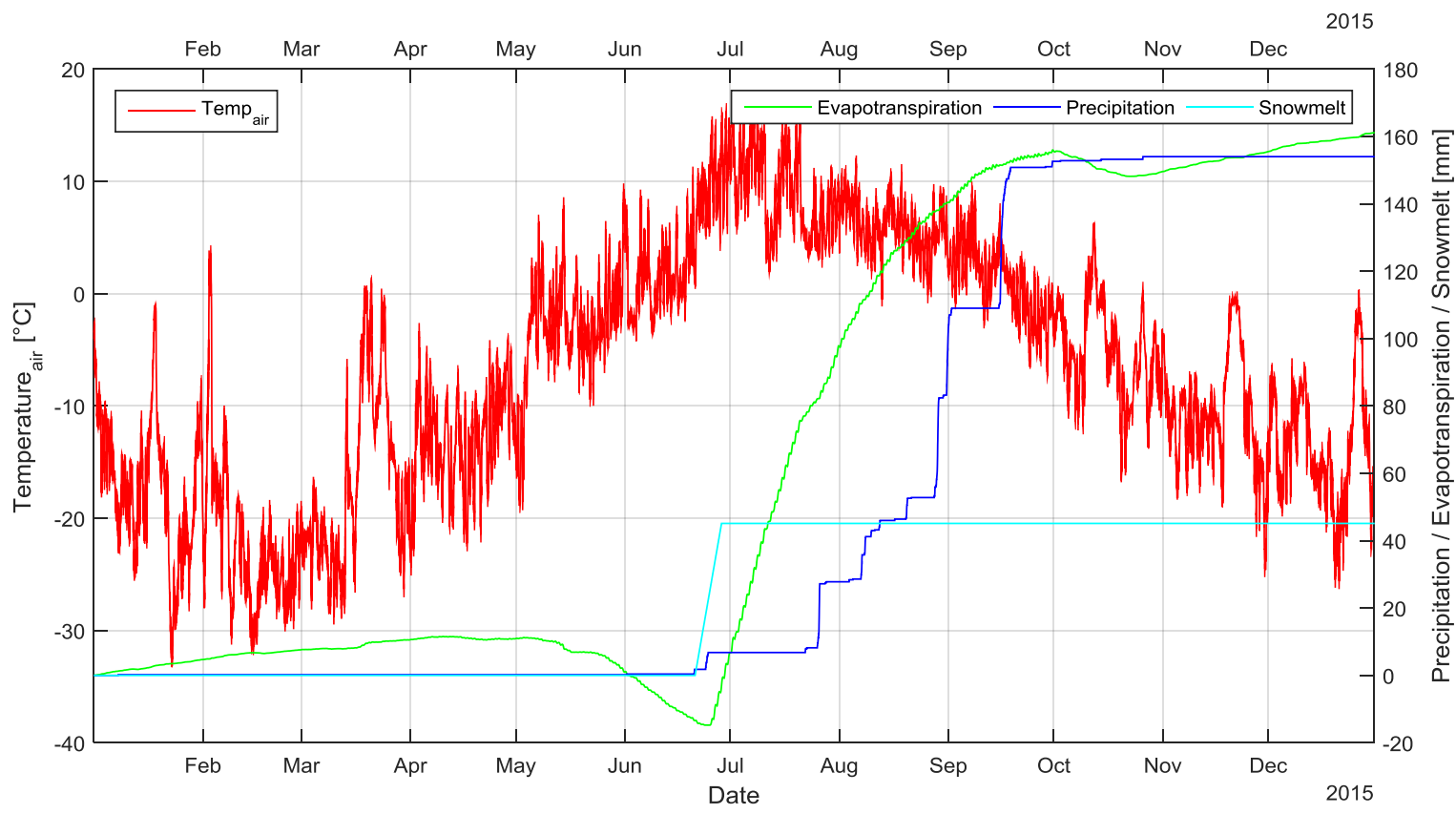

Fig. A1: Temperature and cumulative precipitation, evapotranspiration and snowmelt at the field site for the investigated year 5 2015. Temperature and precipitation measured at AWS3. Snowmelt calculated by Equation 3 and evapotranspiration by Equation 1 based on data from AWS2.

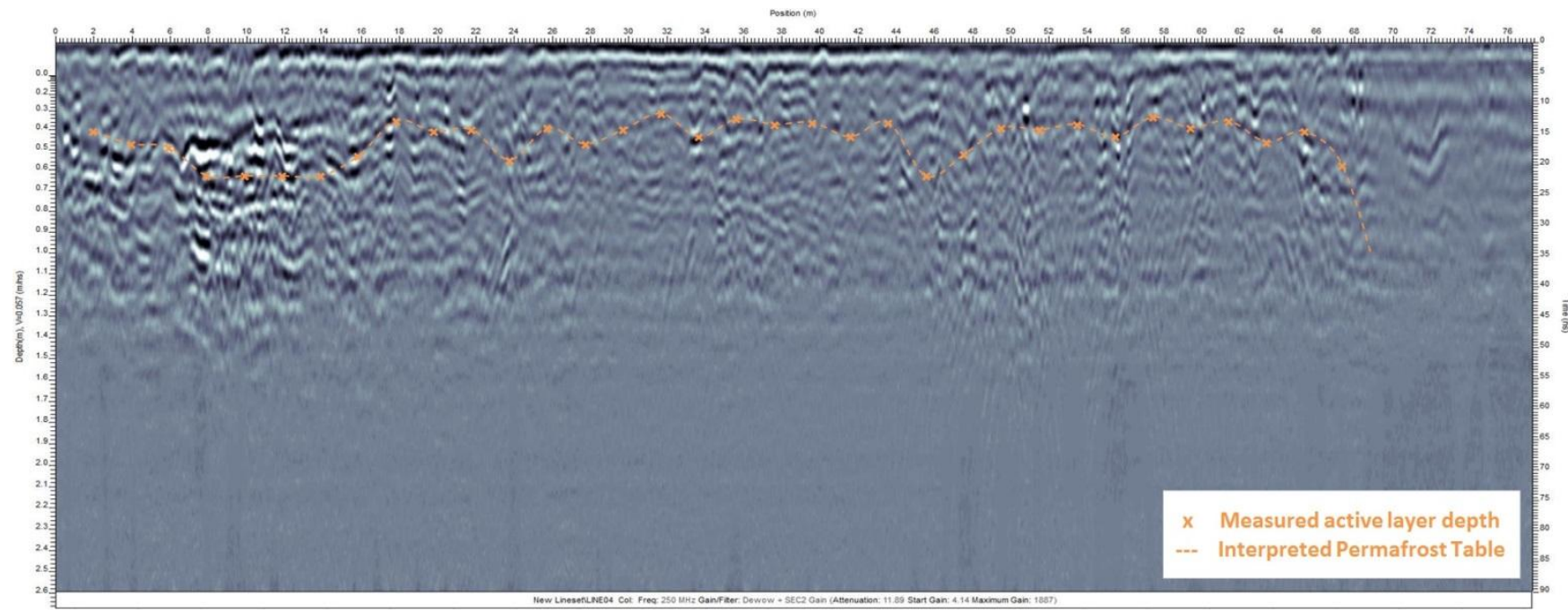

Fig. A2: Interpretation of GPR profile running parallel to the ERT profile (topography not included for better visibility). 
The Cryosphere Discuss., https://doi.org/10.5194/tc-2017-97

Manuscript under review for journal The Cryosphere

Discussion started: 15 June 2017

(c) Author(s) 2017. CC BY 3.0 License.

(c) ${ }_{\mathrm{BY}}$

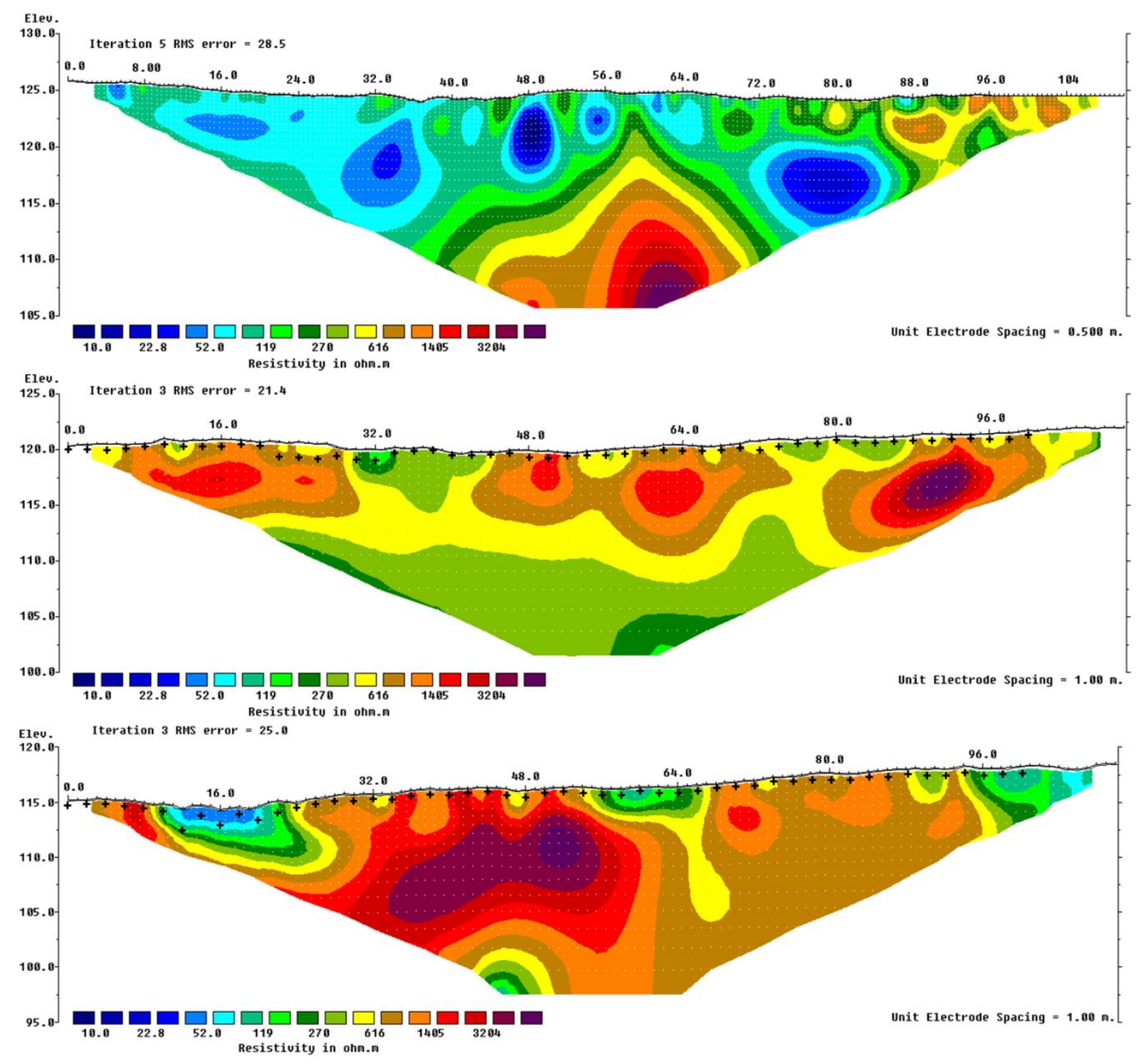

Fig. A3: ERT inversion results for profiles top, middle and bottom all perpendicular to the slope. Crosses indicate measured ALD with stick probing. 
The Cryosphere Discuss., https://doi.org/10.5194/tc-2017-97 Manuscript under review for journal The Cryosphere Discussion started: 15 June 2017

(c) Author(s) 2017. CC BY 3.0 License.

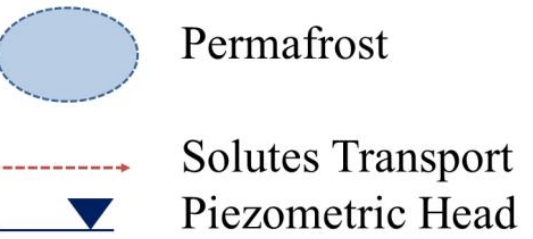

\section{Changing between up and downward flux}

Nutrients end up in active layer

$=$ Bioavailable

$=$ Rapid movement
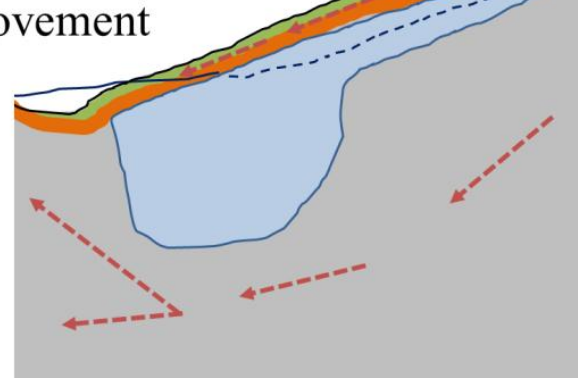

Nutrients end up in subpermafrost aquifer $=$ Not Bioavailable $=$ Slow movement

Fig. A4: Conceptual model of the field site. 
The Cryosphere Discuss., https://doi.org/10.5194/tc-2017-97

Manuscript under review for journal The Cryosphere

Discussion started: 15 June 2017

(c) Author(s) 2017. CC BY 3.0 License.

\section{Water}

Fluid compressibility

Fluid diffusivity

Density of fluid at base concentration

Coefficient of fluid density change with concentration

fluid viscosity

Matrix

Solid matrix compressibility

Density of a solid grain

Porosity_AT

Porosity_CT

Porosity_Till

K_AT

K_CT

K_Till

Van GenuchtenParameters

a_AS

a_CT

n_AT

n_CT

S_res_AT

S_res_CT

Other

Gravity

Dispersivity

Boundary Condition

Top

Precipitation

Interception factor (Fraction retained by vegetation)

Evapotranspiration

Snowmelt equivalent

Snowmelt duration

Snowmelt infiltration (SWE that saturate

Active Layer)

Left

Right - Active layer

Right - Deep

Bottom
Value

Unit

$4.47 \cdot 10^{-10}$

1

1000

877

$1 \cdot 10^{-3}$

$1 \cdot 10^{-8}$

2200

0.97

0.9

0.54

$1.0 \cdot 10^{-4}$

$1.7 \cdot 10^{-4}$

$1.2 \cdot 10^{-8}$

$8.0 \cdot 10^{-4}$

$3.5 \cdot 10^{-4}$

1.9

3.18

0.04

0.053

9.81

0.125

Direct measurement

0.2

$(-)$

Priestly-Taylor with dynamic alpha

225

360

$\mathrm{mm}$

$\mathrm{h}$

0.8

$(-)$

Seepage face $(\mathrm{p}=0)$

no flow

no flow

no flow

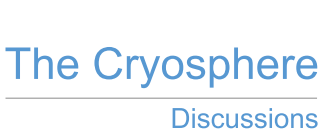

Discussions
Explanation / Source

Density with $\mathrm{NaCl}$

Al-Sheemeri 2012

Soil samples - averaged

Soil Sample - calibrated

Soil Sample - calibrated

Henry 1982 - calibrated

Soil Sample - calibrated

Soil Sample - calibrated

Henry 1982 - calibrated

Letts

USDA

Letts

USDA

Letts

USDA

$(-)$

Inverse modelling from breakthrough curve (using CXT-FIT)

Weather Station 500m distance

calibrated

Weather Station 4000m distance

Dewalle\&Rango 200

Weather Station 500m distance

calibrated

Wetland

Water divide at crest assumed low $\mathrm{K}$ and little pressure difference

confining bedrock

Table A1: Parameters and values used in the model set up. 